\title{
The Parallel Worlds of Corporate Governance and Labor Law
}

Peer Zumbansen

Osgoode Hall Law School of York University, pzumbansen@osgoode.yorku.ca

Follow this and additional works at: https://www.repository.law.indiana.edu/ijgls

Part of the International Law Commons, and the Labor and Employment Law Commons

\section{Recommended Citation}

Zumbansen, Peer (2006) "The Parallel Worlds of Corporate Governance and Labor Law," Indiana Journal of Global Legal Studies: Vol. 13 : Iss. 1 , Article 9.

Available at: https://www.repository.law.indiana.edu/ijgls/vol13/iss1/9

This Symposium is brought to you for free and open access by the Law School Journals at Digital Repository @ Maurer Law. It has been accepted for inclusion in Indiana Journal of Global Legal Studies by an authorized editor of Digital Repository @ Maurer Law. For more information, please contact rvaughan@indiana.edu.

\section{$\Psi$}

JEROME HALL LAW LIBRARY

$$
\begin{aligned}
& \text { INDIANA UNIVERSITY } \\
& \text { Maurer School of Law }
\end{aligned}
$$

Maurer School of Law
Blooming ton 


\title{
The Parallel Worlds of Corporate Governance and Labor Law
}

\author{
Peer Zumbansen*
}

Abstract

This paper engages the concept of transnational law $(T L)$ in a way that goes beyond the by now accustomed usages with regard to the development of legal norms and the observation of legal action across nation-state boundaries, involving both state and nonstate actors. The concept of TL can serve to illustrate a much further-reaching set of developments in norm creation and legal regulation. TL is here understood not only as a body of legal norms, but it is also employed as a methodological approach to illustrate common and shared challenges and responses to legal regulatory systems worldwide. In the case of corporate governance, TL captures the specific regulatory mix of formal, hard, public regulation, on the one hand, and of informal, soft, private regulation, on the other, that characterizes the contemporary evolution of corporate governance norms. Corporate governance norms give testimony of an ongoing search for answers to persisting problems in the organization of the firm, the distribution of power between shareholders, stakeholders, and the firm, as well as the responsibility of the corporation to its environment while-at the same time-reflecting on fundamental changes of the nature of norm creation and legal interpretation. While this approach is likely already to undermine some of the contentions regarding a universal

*Canada Research Chair in the Transnational and Comparative Law of Corporate Governance, Osgoode Hall Law School, York University, Toronto, Canada (http:/www. osgoode.yorku.ca/faculty/peerzumbansen.html). Director, CLPE Comparative Research in Law and Political Economy Network, http://www.comparativeresearch.net; Co-Editor-in-Chief, German Law Journal, http:/www.germanlawjournal.com. E-mail: Pzumbansen@osgoode. yorku.ca. This paper was first presented at the 13th Annual Conference of the Indiana Journal of Global Legal Studies: Globalization and the New Politics of Labor, Indiana University School of Law-Bloomington (Feb. 12, 2005). I am grateful to Alfred Aman, Jr. for his invitation and his and the other participants' comments. A subsequent presentation was given at the Canadian Centre for German and European Studies at York University, Toronto (www.ccges.ca) and at the Globalization and Its Discontent Colloquium at New York University School of Law. I am grateful to Benedict Kingsbury and Philip Alston for their kind invitation and their very helpful comments. I also want to thank Harry Arthurs, John Cioffi, Doreen Lustig, Gregory Smith and Peter Zwiebach for their comments. Amar Bhatia and Nuri Frame at Osgoode Hall provided excellent research assistance. 
convergence of corporate governance systems towards an outsider-control, shareholdervalue-maximization model at the "end of history of corporate law," its risks lie in the misappropriation of the described processes of private ordering as processes of natural evolution. After all, the shift away from formal law making to processes of societal self-regulation - as reflected in the rise of corporate governance codes, standards, best practices or; in the area of labor law, of codes of conduct and core labor rights-might turn out to be a less fortunate answer to the redistributive and participatory questions that are posed when one views corporate governance in the context of a larger set of welfare state norms, comprising not only company law and securities regulation, but also labor and employment law, industrial relations, and insolvency law. Eventually, a careful study of the transformation of the process of law making and rule enforcement suggests the necessity of taking a broader view on corporate governance than is often the case. Seen against the background of a globalization of economic activity, capital flows, and the erosion of many protective norms and rights-in particular in the area of labor law- the study of transnational corporate governance can contribute to a better understanding of the regulatory challenges of a globalized market economy.

\section{INTRODUCTION}

The transterritorialization of company activities that span the globe-with widespread subsidiaries, interfirm networks, and extreme forms of outsourcing of formerly corporate-owned processes-challenges traditional regulatory aspirations of nation-states and other political bodies. ${ }^{\prime}$ Corporate activity is disintegrated into a multitude of decentralized, and yet connected, processes. This state reflects on the dramatic changes of the nature and structure of the private business corporation and of the marketplace in which it operates. With corporate activity encompassing the production of cars, tank ships, microchips, medical and spaceflight software, precision weapons, and throw-away toys to help uninventive hosts of children's birthday parties, no end is in sight to a feverishly progressing diversification of products and methods for their branding, assembly, and

1. Peter Hertner, Corporate Governance and Multinational Enterprise in Historical Perspective, in Comparative Corporate Governance: The State of the Art and Emerging Research 41 (Klaus J. Hopt et al. eds., 1998); see Mark Herkenrath \& Volker Bornschier, Transnational Corporations in World Development: Still the Same Harmful Effects in an Increasingly Globalized World Economy?, 9 J. World-Systems Res. 105 (2003). 
dissemination. ${ }^{2}$ Dell, the computer firm, made use of the "three new freedoms" in the 1990s-to conduct business without borders, to conduct business "unburdened by any sense of responsibility to any community or any individual," and to conduct it in the wake of a technological revolution that allowed for an unprecedented extension of the assembly line ${ }^{3}$ - exemplifying a much larger trend, whose sources and driving forces date to at least a century prior. The "Dell Effect" describes a computer manufacturing and sales unit that can custom assemble and deliver computers anytime and anywhere in the world, that has dramatically cut down on inventory times and, much like Wal-Mart, integrated its thousands of business partners, suppliers, assemblers, and transporters in a worldwide logistical web. It must today be seen to embody much of what Manuel Castells rightly coined the "Network Society," and what others refer to as the "Digital Revolution." The stories are no less than breathtaking:

As other companies struggled to reorganize their internal operations, to contract out more work, to blend in more overseas sources of supply, [Michael] Dell focused on using the latest in supply-chain management software to coordinate the movement of components from wherever he could get them. Almost entirely unrestrained by existing in-house component-manufacturing operations, Dell concentrated instead on developing a system that could track individual items-no matter where they were made-more tightly and efficiently than was possible even in the most perfectly integrated of old-line companies. For Dell, manufacturing was not making things, it was buying and moving and

2. See generally Naomi Klein, No Logo: Taking Aim at the Brand Bullies (1st Picador USA ed. 2001) (1999).

3. Barry C. Lynn, End of the Line: The Rise and Fall of the Global Corporation 103 (2005).

4. See Dell Inc., The Dell Effect: Expanding Access and Changing the World 1-2, http:// www.dell.com/downloads/global/corporate/delleffect/DellEffect.pdf; Dell Global Product Development, http://wwwl.us.dell.com/content/topics/global.aspx/innovation/en/cto_product_ development ${ }^{c}=$ us\&l=en\&s = corp (detailing Dell's innovation centers in Texas, India, China, Taiwan, and Malaysia).

5. 1 Manuel Castells, The Information Age: Economy, Society and Culture: The Rise of the Network Society (2d ed. 2000).

6. Jack Challoner, The Digital Revolution (2002). 
assembling and delivering things that other companies had manufactured. $^{7}$

Michael Piore and Charles Sabel have identified the enormous social, economic, and political consequences of Taylorist scientific production forms, ${ }^{8}$ standardization of work tasks, and the construction of markets for mass consumer goods through the technological revolution in the nineteenth century as the "Second Industrial Divide." These phenomena seem mere precursors to present developments, the impact of which we recognize as still more radical and untamable than the former. While the welfare state arose ${ }^{10}$ out of the dire situation of rural desertion, urban poverty, and industrial workers' hardship, ${ }^{11}$ no such utopian model offers itself at the outset of the twenty-first century. With the Western welfare state struggling to rediscover its institutional promise for the future, ${ }^{12}$ the answers to the regulatory challenges of globalized markets are increasingly sought elsewhere.

In this new globally competitive economy, the exploited human beings with whose dignity and welfare the founders of labour laws were concerned, are now most likely to be found in sweat shops in South Asia or the Caribbean producing clothes for supermarkets in Europe and America; or in slum factories in East Asia assembling circuit boards for transnational IT companies. ${ }^{13}$

7. LxNn, supra note 3 , at 102.

8. See Michael J. Piore \& Charles F. Sabel, The Second Industrial Divide: Possibilities for Prosperity 45-46 (1984). The term Taylorism goes back to the particular form of mass production conceptualized in Frederick Winslow Taylor, The Principles of Scientific Management (1911).

9. Piore \& Sabel, supra note 8 , at 6.

10. See Paul Pierson, The New Politics of the Welfare State, 48 World Pol. 143 (1996); Philip Manow, Welfare State Building and Coordinated Capitalism in Japan and Germany, in The Origins of Nonliberal Capitalism 94, 95 (Wolfgang Streeck \& Kozo Yamamura eds., 2001).

11. See generally Karl Polanyi, The Great Transformation: The Political and Economic Origins of Our Time (2d ed., Beacon Press 2001) (1944); Upton Sinclair, The Jungle (Random House 2002) (1906) (providing an account of the bleak and violent conditions of workers in Chicago's stockyards in novel form).

12. See Jürgen Habermas, The New Obscurity: The Crisis of the Welfare State and the Exhaustion of Utopian Energies, in The New Conservatism: Cultural Criticism and the Historians' DeвAтE 48, 50-51, 54, 59 (Shierry Weber Nicholsen ed. and trans., 1989).

13. Bob Hepple, Labour Laws and Global Trade 5-6 (2005). 
The characterization of economic globalization as the worldwide interaction of global trading partners is paralleled by an unprecedented economic interdependence of industry branches and their respective human and institutional communities and stakeholders around the world. This interdependence results from firms relying on the cheapest labor, on export-processing zones, and on justin-time delivery of elements from innumerable places and directions. ${ }^{14}$ This highly sensitive system of interlocking production and delivery processes constitutes an overwhelming challenge for traditional conceptions of business corporations, of their relations to business partners, and of stakeholders, such as employees and the community in which a business operates. Underneath the shining layer of universally available standard goods, unrestrained by seasonal changes or other local conditions, we find a pulsating network of fine arteries connecting a multitude of actors' lives, each delivered to this massive and sprawling machinery. The "state as machine" ${ }^{15}$ has seemingly found its master.

The focus of this paper is on the changes in legal regulation of transnational corporate activity. The study of the structure of contemporary legal regulation is rendered difficult through the proliferation of "spaces and places" of norm generation..$^{16}$ As a result, an exploration of the law applicable to domestic and global corporate activity must trespass disciplinary boundaries, as the norms that corporations follow (or seek to escape) encompass corporate law rules, the rules of taxation law and labor law, which together shape the regulatory environment of the contemporary corporation. But, such exploration must also illuminate the tension between the place of the business operation and the locally applied norms ("place"), and the decentered reality of the corporation and the norms that are emerging to address this delocalized phenomenon of corporate activity ("space"). While the political economy of domestic corporate and labor regulation is still characterized by contested traditions of institutional and political heritage and disciplinary boundaries and power, ${ }^{17}$ the regulatory environment

14. See id. at $13-14$.

15. Horst Dreier, Hierarchische Verwaltung im demokratischen Staat 19-36 (1991).

16. See generally Saskia Sassen, Globalization and Its Discontents: Essays on the New MoBility of People and Money (1998). Cf. J. Rogers Hollingsworth, New Perspectives on the Spatial Dimensions of Economic Coordination: Tensions Between Globalization and Social Systems of Production, 5 Rev, of Int'L Pol. Econ. 482, 487 (1998). See also Adelle Blackett, Global Governance, Legal Pluralism and the Decentered State: A Labor Law Critique of Codes of Corporate Conduct, 8 IND. J. Global Legal Stud. 401, 403-04, 426 (2001); Peer Zumbansen, Spaces and Places: A Systems Theory Approach to Regulatory Competition in European Company Law, 12 Eur. L. J. (forthcoming 2006).

17. See generally Kathleen Thelen, Varieties of Labor Politics in the Developed Democracies, in Varieties of Capitalism 71 (Peter A. Hall \& David Soskice eds., 2001). 
of corporations and laborers operating on and for global markets increasingly incorporates distinctly transnational elements. States or international organizations are not the sole authors of laws and binding norms. ${ }^{18}$ Domestic statutory and case law (especially in the field of labor law) is complemented by a proliferation of "soft law," corporate governance codes, codes of conduct, best practice guidelines, and standards. Meanwhile, domestic labor law programs and international labor law face the challenge and competition of transnational labor norms, generated by both public and private norm authors that operate with little regard to political and geographical borders. ${ }^{19}$ This proliferation and hybridization of norms in the areas of labor law and corporate law raises multiple questions as to the legal nature of these norms, their authorship, and their enforceability. In a brilliant analysis of this challenge, Adelle Blackett wrote in the Indiana Journal of Global Legal Studies a few years ago:

Workers in EPZs [export processing zones] are thrust into the post-modern system of just-in-time flexible accumulation as they enter the deterritorialized legal order of the multinational enterprises, living and producing their norms. Yet, they do so in particular places that may harken back to the Dickensian conditions of nineteenth-century industrialization. ${ }^{20}$

Underscoring the importance of an astute analysis of the place of regulation against the background of the larger dimensions of economic and regulatory spaces to open up the local framework, she notes later:

18. Niklas Luhmann, Die Weltgesellschaft, 57 Archiv für Rechrs- und SozıalphiLosophie [ARSP] 1 (1971) (F.R.G.); See Gunther Teubner, Review Essay, Breaking Frames: The Global Interplay of Legal and Social Systems, 45 AM. J. Comp. L. 149, 149-50 (1997); Peer Zumbansen, Die vergangene Zukunft des Völkerrechts, 34 Kritische Justiz [KJ] 46 (2001) (F.R.G.) (identifying the absence of a hierarchy of norms in the global sphere).

19. See Hepple, stupra note 13, at 69-87. See generally the discussion between Philip Alston and Brian Langille on the viability of the ILO regime and the merits of core labor rights and standards: Philip Alston, 'Core Labour Standards' and the Transformation of the International Labour Rights Regime, 15 Eur. J. Int'L L. 457 (2004) [hereinafter Alston, Core Labour Standards]; Brian A. Langille, Core Labour Rights - The True Story (Reply to Alston), 16 Eur. J. INT'L L. 409 (2005); Philip Alston, Facing up to the Complexities of the ILO's Core Labour Standards Agenda, 16 Eur. J. INT'L L. 467 (2005) [hereinafter Alston, Facing up].

20. Blackett, supra note 16 , at 405 . 
[B]y explicitly considering the importance of place, corporate codes can broaden the discussion of labor rights to address the frequent inability of developing countries and transition economies to provide functional labor inspection and dispute resolution services, not to mention suitable schools. ${ }^{21}$

The need for such inquiry seems obvious given the evidence of the detrimental effect of deregulated labor markets on workers' conditions, employment hours and protection, wage levels, and training. ${ }^{22}$ In light of the current state of labor law regulation on the domestic and international level, attention has increasingly turned to transnational norms of labor regulation. ${ }^{23}$ But, skepticism rightly prevails regarding the quality of self-regulatory regimes as embodied in corporate codes of conduct or core labor standards. ${ }^{24}$

This calls for a comprehensive study and exploration of the conditions that shape contemporary employment-within domestic markets as well as in developing countries and crucially delegalized export processing zones. Whether or not a transnational labor regime will deliver in the hopes for a better and more effective protection of the rights of workers in today's global economy depends to a large degree on its concrete legal structure. It seems evident that the transnationalization of labor law bears many commonalities with the global reach of corporate governance norms, in particular with regard to the hybridization of the applicable rules into an intricate mixture of hard and soft law, of statutory norms, and of self-regulatory regimes. At the same time, the concerns of labor lawyers will continue to differ dramatically from those of today's corporate lawyers and corporate law scholars. The dire reality of contemporary labor law, embedded in a seemingly universal loss of terrain for both political leverage and scholarly influence, testifies to the field's state of siege. As Douglas Branson remarked,

21. Id. at 431 .

22. Hepple, supra note 13 , at 17. Contra Martin Wolf, Why Globalization Works 220-48 (2004).

23. Roger Blanpain \& Michele Colucci, The Globalization of Labour Standards: The Soft Law Track (2004); Jill Murray, Corporate Codes of Conduct and Labour Standards, http:/www.itcilo.it/english/actrav/telearn/globalilo/guide/jill.htm (last visited Jan. 13, 2006).

24. Hepple, supra note 13, at 11 ("Behind the paper tigers of laws and codes of conduct, is the thriving jungle of the market."). "Private corporate codes exist because of the absence of an enforceable internationally agreed labour regime." Id. at 72 . 
Worker exploitation, degradation of the environment, economic imperialism, regulatory arbitrage, and plantation production efforts by the growing stable of gargantuan multinationals, whose power exceeds that of most nation states, is far higher on the global agenda than is convergence in governance. ${ }^{25}$

It is against these regimes' different prospects for the future that the inquiry into the transnationalization of corporate and labor norms needs to be conceptualized. Hence, the study of what might be understood as an emerging transnational law of corporate governance has to focus on the various existing regulatory frameworks for business corporations on the domestic, transnational, and international level. Conceptualizing the norms that shape the "constitution of the firm" as a transnationally evolving body of $l a w^{26}$ helps to illuminate the embeddedness of firms in layers of rules. ${ }^{27}$ Business corporations and the norms that govern them must be understood in the context of their origin and development in specific systems of production, ${ }^{28}$ as well as in legal and socioeconomic cultures. ${ }^{29}$ The transnational law of corporate governance encompasses the hard law that governs the corporation through domestic company law, securities regulation, tax law, or labor law, on the one hand, and the soft law of voluntary codes of conduct, corporate governance codes, human rights codes, and core labor standards, on the other.

25. Douglas M. Branson, The Very Uncertain Prospect of "Global" Convergence in Corporate Governance, 34 CoRnell Int'L L.J. 321, 326 (2001).

26. See Christine A. Mallin, Corporate Governance ch. 3 (2004).

27. See generally Andrew Shonfield, Modern Capitalism: The Changing Balance of Public and Private Power (1965); Robert Boyer \& J. Rogers Hollingsworth, From National Embeddedness to Spatial and Institutional Nestedness, in Contemporary Capitalism: The Embeddedness of Institutions 433 (J. Rogers Hollingsworth \& Robert Boyer eds., 1997); Mark Granovetter, Economic Action and Social Structure: The Problem of Embeddedness, 91 AM. J. Soc. 481 (1985); Peer Zumbansen, The Privatization of Corporate Law?: Corporate Governance Codes and Commercial SelfRegulation, Juridikum (F.R.G.), Mar. 2002, at 32.

28. See Sanford M. Jacoby, The Embedded Corporation: Corporate Governance and Employment Relations in Japan and the United States (2005); Michael Storper \& Robert Salais, Worlds of Production: The Action Frameworks of the Economy (1997).

29. See generally Richard Whitley, The Social Construction of Economic Actors: Institutions and Types of Firms in Europe and Other Market Economies, in The Changing European Firm 39 (Richard Whitley \& Peer Hull Kristensen eds., 1996); Richard Whitley, Divergent Capitalisms (2d ed. 2000); Robert Boyer, Hybridization and Models of Production: Geography, History, and Theory, in Between Imitation and Innovation 23 (Robert Boyer et al. eds., 1998); Systems of Production: Markets, Organisations and Performance (Brendan Burchell et al. eds., 2003). See also Mark J. Roe, Strong Managers, Weak Owners (1994). 
As the latter present a dramatic challenge to traditional understandings of law making, an analysis of voluntary codes of conduct further illuminates the complex nature of the regulated and self-regulating firm. But the inquiry into the transnationalization of corporate and labor norms reveals a much less natural or unavoidable development than is often thought. Instead of understanding the new politics of labor as illuminating and assessing an inevitable development, quasi-naturally accompanying the globalization of commercial activity, this process must be studied with much closer attention to the political constellations in which choices are made. ${ }^{30}$ The move of legal analysis beyond the confines of the nation-state must incorporate the lessons learned from previous studies of regulatory change in domestic welfare-state regimes, in order to ask the right questions when confronted with the plethora of self-regulatory norms, codes of best practice, codes of conduct, and core standards. In addition, the comparative view on both corporate and labor law shall allow bridging some of the bifurcations that characterize the commonly separated fields of law. While, in labor law, a distinct critique of self-regulation and an erosion of enforceable rights have been unfolding over the past few years, ${ }^{31}$ the same cannot be said of contemporary mainstream scholarship in the area of corporate law. Here, the discourse seems to be predominantly determined by ongoing concerns with issues of "ownership and control" and an alleged convergence of corporate governance rules toward a shareholder-value maximization model.$^{32}$ After important studies exploring the political economy of the corporation, ${ }^{33}$ the focus on the

30. See Karl Klare, The Horizons of Transformative Labour and Employment Law, in LABouR Law in an Era of Globalization 3 (Joanne Conaghan et al. eds., 2002); Joanne Conaghan, Women, Work, and Family: A British Revolution?, in Labour Law in an Era of Globalization, supra, at 53.

31. See H.W. Arthurs, Labour Law without the State?, 46 U. Tononto L.J. 1 (1996); Manfred Weiss, The Future of Comparative Labor Law as an Academic Discipline and as a Practical Tool, 25 Comp. Lab. L. \& Pol'y J. 169 (2003); Alston, Core Labour Standards, supra note 19; Philip Alston, Labour Rights as Human Rights: The Not So Happy State of the Art, in Labour Rights as Human Richts 1 (Philip Alston ed., 2005); Simon Deakin, Social Rights in a Globalized Economy, in LAbour Rights as Human Rights, supra, at 25. But see Langille, supra note 19.

32. See Henry Hansmann \& Reinier Kraakman, Essay, The End of History for Corporate Law, 89 GEo. L.J. 439 (2001) (subsequently republished in different collections). For an early, quite vehement critique of the Hansmann \& Kraakman article, see Branson, supra note 25, at 330-31 (calling it a "chauvinistic statement of the Americanocentric convergence thesis").

33. Walther Rathenau, Vom Aktienwesen (1917); Adolf A. Berle, Jr., The 20th Century Capitalist Revolution (1954); Shonfield, supra note 27. 
law-making aspects of corporate norms is much more recent. ${ }^{34}$ Only from this perspective can we arrive at a more precise and adequate picture of the role of law in shaping the constitution of the firm. Deciphering this role is important in view of the manifold functions that today's firms perform on the domestic and the transnational level. These functions of the firm include: the furthering of prosperity for shareholders and stakeholders such as employees, creditors, and the community at large; guaranteeing employee pension plans $;{ }^{35}$ investing in research and development; and disseminating resulting knowledge, as well as engaging in the protection of the environment or observing cultural requirements and human rights standards in the firm's operation in various political contexts. In addition, as firms offer themselves as prime agents of technological innovation, their role within regional and national economies is of utmost importance under conditions of global competition. Noting a recently heightened awareness among policy makers in Canada, the United States, and the European Union of the need to strengthen the innovative potential of their economies, it is mandatory to better understand the role of business corporations and the potential for, but also the shortcomings of, regulatory approaches in this respect. ${ }^{36}$

The first Part of this article explores the different genealogies and trajectories of corporate law and labor law as the two great, opposed building blocks of

34. Theodor Baums, Reforming German Corporate Governance: Inside a Law Making Process of a Very New Nature -Interview with Professor Dr. Theodor Baums, German L.J., July 16, 2001, http:// www.germanlawjournal.com/past_issues.php?id=43; John W. Cioffi, Governing Globalization? The State, Law, and Structural Change in Corporate Governance, 27 J.L. \& Soc'y 572 (2000); Zumbansen, supra note 27.

35. See Donald J. Johnston, Foreword to Org. for Econ. Co-Operation and Dev., OECD Principles of Corporate Governance 3-4 (rev. ed. 2004), http://www.oecd.org/dataoecd/32/18/ 31557724.pdf ("In today's economies, interest in corporate governance goes beyond that of shareholders in the performance of individual companies. As companies play a pivotal role in our economies and we rely increasingly on private sector institutions to manage personal savings and secure retirement incomes, good corporate governance is important to broad and growing segments of the population.").

36. Org. for Econ. Co-Operation and Dev., supra note 35, at 13-14 ("The Principles are evolutionary in nature and should be reviewed in light of significant changes in circumstances. To remain competitive in a changing world, corporations must innovate and adapt their corporate governance practices so that they can meet new demands and grasp new opportunities. Similarly, governments have an important responsibility for shaping an effective regulatory framework that provides for sufficient flexibility to allow markets to function effectively and to respond to expectations of shareholders and other stakeholders."). 
the "political economy of the firm." ${ }^{37}$ In the context of this article, the focus in Part II.A. will be on the different regulatory foci of corporate and labor law and their respective images and concepts of the corporation, its stakeholders, and its role in society. This first comparison of the different worlds of corporate and labor law serves as a prerequisite for the closer scrutiny of the changes in regulatory method that have been taking place in both fields. The changes in corporate law, through the comparative study and impact of foreign corporate governance rules and through the issuance of corporate governance recommendations and standards through private and quasi-public bodies on the domestic and international level, have nurtured belief in a universal convergence of corporate governance rules. And yet, contestations remain strong. This is the focus of Part II.B. of this article. The last Part explores the larger context of a turn to standards, recommendations, and corporate self-regulation against the background of international law's long-standing soul-searching. ${ }^{38}$ We enter ardent debates over the viability of legal regulatory frameworks in an increasingly globalized society. ${ }^{39}$ Whether it is possible to transport and translate our understanding and experiences of the rule of law and "fora, forms and processes" of legal delibera-

37. See generally The Political Economy of the Company (J.E. Parkinson et al. eds., 2000). The inquiry into the no less important political economy of taxation law in shaping the regulatory environment of the firm will be pursued in a subsequent paper. See, e.g., Neil Brooks, The Logics, Policy and Politics of Tax Law', in Materials on Canadian Income Tax Law (Tim Edgar et al. eds., 12th ed., Carswell 2000).

38. On the ongoing introspection among international lawyers on their field, see Manley $O$. Hudson, The Prospect for International Law in the Twentieth Century, 10 CoRnell L.Q. 419 (1925); see also Marti Koskenniemi, International Law in Europe: Between Tradition and Renewal, 16 EuR. J. INT'L L. 113 (2005).

39. See the breathtaking concluding chapter in Niklas Luhmann, Law as a Social System (Ziegert Fatima Kastner et al. eds., Klaus A. Ziegert trans., 2004). See also Luhmann, supra note 18. More recently in this context, see Andreas Fischer-Lescano \& Gunther Teubner, Regime-Collisions: The Vain Search for Legal Unity in the Fragmentation of Global Law, 25 MicH. J. INT'L L. 999 , 1003 (2004) ("Neither doctrinal formulas of legal unity, nor the theoretical ideal of a norm hierarchy, nor the institutionalization of jurisdictional hierarchy provide an adequate means to avoid such conflicts."). On the theme of a non-hierarchical, global legal order, see Peer Zumbansen, Beyond Territoriality: The Case of Transnational Human Rights Litigation (Constitutionalism Web-Papers, ConWEB No. 4/2005), available at http://www.qub.ac.uk/schools/ SchoolofPoliticsInternationalStudiesandPhilosophy/FileStore/ConWEBFiles/Filetoupload, 16448,en.pdf. On Luhmann's concept of law as a globalizing social system, see Peer Zumbansen, Notes on the Fragility of Law: A Review Essay on Niklas Luhmann's Law as a Social System, 17 Soc. \& LEGAL STUd. (forthcoming 2006). 
tion ${ }^{40}$ into the realms of disintegrated social activity goes to the heart of our reliance on law as a means of social regulation. But, instead of suggesting that the turn to codes of conduct be read as the swan song of the rule of law, the concluding part highlights the stakes of corporate self-regulation and the rise of labor standards in light of the fragility of rights and enforcement procedures in a complex and fragmented global society.

\section{Studying Corporations, Their Stakeholders, and Their Law}

Corporate law and labor law inhabit two distinct and separate worlds of legal thought - and of political reality. Corporate governance codes and corporate codes of conduct endorsing labor norms ${ }^{41}$ mirror the existing tension inherent to different groups in the legal and economic fields. Both groups of actors are protagonists in different narratives describing the reality of globally integrated markets and the new economy. In one narrative, we find contract and property considerations turning on management control. For corporate law, its primary regulatory focus is on shareholder value. With regard to the regulatory context, corporate law is embedded within a larger programmatic frame where structural considerations regarding the business corporation-"legal personality, limited liability, transferable shares, delegated management.... and investor ownership" 42 - are perceived to be akin to policies focusing on investor protection, financial stability, and "good governance." 43

In contrast, the labor law narrative illustrates an increasingly endangered range of rights for workers and the need to adapt the applicable legal regime to the economic realities that have come upon us. ${ }^{44}$ As the economic environment continues to change dramatically, allowing for a radical flexibility of capital and

40. Rudolf Wiethölter, Materialization and Proceduralization in Modern Law, in Dilemmas of LaW in the Welfare State 221 (Gunther Teubner ed., 1986).

41. See the excellent introduction on the ILO's website. Corporate Codes of Conduct, http:// www.itcilo.it/english/actrav/telearn/global/ilo/code/main.htm (last visited Jan. 13, 2006).

42. Henry Hansmann \& Reinier Kraakman, What Is Corporate Law?, in The Anatomy of CoRPORATE Law 1 (2004).

43. See World Bank, World Development Report 2002: Building Institutions for Markets 55-74 (2002), available at http:/www.worldbank.org/wdr/2001/fulltext/ch3.pdf; Kerry Rittich, The Future of Law and Development: Second Generation Reforms and the Incorporation of the Social, 26 Mich. J. INT'L L. 199 (2004).

44. See the debate between Alston and Langille: Alston, Core Labour Standards, supra note 19; Langille, supra note 19; Alston, Facing up, supra note 19. 
work, workers are threatened by the loss of many of their institutional and regulatory safeguards. Attempts to reinvigorate labor rights and worker protection are hampered by international pressure to provide attractive economic environments. Where rights for workers are demanded by developing countries, these nations fear yet another protectionist backlash from developed states.

It can be shown, however, that these narratives actually do not describe separate worlds but are instead two sides of the same coin. Both tell the story of powerful changes in societal governance through law. Beyond the conflation of different "models of democracy," 45 there exists a crucial parallel between the regulatory challenges faced by public actors, such as states and international bodies and the ever-growing freedoms of transnationally operating corporations. The transformations in governance brought about by the denationalization of societal activity, ${ }^{46}$ by technological advances, and by an irreversible interpenetration of public and private sites of power and identity, ${ }^{47}$ are reproducing themselves in our debates over substance (What is the corporation? Whose firm is it?) and procedure (How do norms come about? Are codes law?). Central to both narratives are changes in their respective legal regime. But, while these legal transformations can be understood as reacting to similar challenges-the difficulty of extending nation-states' regulatory reach to foreign operating business organizations, a proliferation of norm-making actors and levels, and a complex coexistence of hard law and soft law ${ }^{48}$ - there remains a great need to further explore these transformations of legal regulation. While labor law now needs to find its institutional and normative holding in globally integrated markets and a drastically changed regulatory environment, corporate governance seems to reflect the bright side of the recent new economy-here,

45. David Held, Models of Democracy (2d ed. 1997); Robert A. Dahl, On Democracy (2000); Jürgen Habermas, Three Normative Models of Democracy, in The Inclusion of the Other 239 (Ciaran Cronin \& Pablo De Greiff eds., 1998).

46. See genierally Luhmann, supra note 18; LuhmanN, supra note 39; Saskia Sassen, Globalization or Denationalization?, 10 Rev. INT'L PoL. Econ. 1 (2003).

47. Sally Falk Moore, Lawand Social Change: The Semi-Autonomous Social Field as an Appropriate Subject of Study, 7 L. \& Soc'y Rev. 719 (1973); Sally Engle Merry, Anthropology, Law, and Transnational Processes, 21 Ann. Rev. Anthropology 357 (1992); Gunther Teubner, 'Global Bukowina': Legal Pluralism in the World Society, in Global Law Without a State 3 (Gunther Teubner ed., 1997); Peer Zumbansen, Traninational Law, in Encrclopedia of Comparative Law (Jan Smits ed., forthcoming 2006).

48. See Boaventura de Sousa Santos, Toward a New Legal Common Sense: Law, GlobalizaTION, ANd EMancipation (2002). In this vein, see Jean-Philippe Robé, Multinational Enterprises: The Constitution of a Pluralistic Legal Order, in Global Law Without a State, supra note 47, at 45, 55. 
everyone drives a BMW and concludes business deals over the Internet. The perceived changes in norm production in corporate governance evoke an apparently altogether different and dissociated discourse on the chances and dynamics of global markets from the narrative of the rise and fall of labor law.

In order to further illustrate the tension between the worlds of corporate governance and labor law, I will sketch some significant elements of the political economy of both fields and disciplines. Against this background, then, we can discern fundamental problems of analogizing the rise of quasi-universal corporate governance concepts (such as shareholder-value maximization) with the emergence of corporate codes of conduct and core labor standards. While the former are representative of a far-reaching transformation of the rules pertaining to business organization in order to make business management more responsive to investor needs, the development of labor standards that depend on their recognition by states and private corporate actors and of corporate codes of conduct that remain enforceable only on a voluntary basis, reflects on the increasingly fragile standing of labor law in the global regulation of the economy. The claim to fame of the corporate governance movement at the beginning of the twenty-first century might be the flipside of the longstanding deterioration of labor rights and an effective labor rights regime.

\section{A. Exploring the Geography of the "Worlds" of Corporate Governance and Labor Law}

\section{Regulatory Framework}

\section{a. Corporate Governance}

With regard to the policy program of corporate governance, we find an eternal struggle with the separation of "ownership and control." This is not a new topic, ${ }^{49}$ but is one that has been powerfully exacerbated by the recent financial scandals in the United States and elsewhere..$^{50}$ The problem of the separation of ownership and control boils down to more specific inquiries into corporate per-

49. See Adolf A. Berle \& Gardiner C. Means, The Modern Corporation and Private PropERTY (rev. ed. 1968).

50. See generally Margaret M. Blair, Post-Enron Reflections on Comparative Corporate Governance, 14 J. Interdisc. Econ. 113 (2003); Lyman Johnson, After Enron: Remembering Loyalty Discourse in Corporate Law, 28 Del. J. Corp. L. 27 (2003). 
sonality and limited liability, ${ }^{51}$ managerial power, and minority protection..$^{52}$ In light of related discussions, we can discern the "purpose" of the corporation to be the generation of profit for shareholders. ${ }^{53}$ Control has always been a contested concept, invoking countervailing conceptual approaches; control ought to be exercised either through internal organization or the market, inner-firm instruments of management supervision with or without independent directors, or takeovers. ${ }^{5+}$ While the latter clearly points to the embeddedness of corporate law in a wider frame of regulatory politics and path-dependent corporate trajectories, ${ }^{55}$ a microanalysis of corporate law remains restricted to an inside view of the corporation. Corporate law remains confined to the "ownership and control" model that is exclusively oriented around financial ownership. Human capital investment, in contrast, ${ }^{56}$ is not considered on the same level as financial investment. Eventually, the combination of financial transparency goals promoted and enforced by the Securities Exchange Commission (SEC), and the protection of managerial prerogatives, led to a forceful exclusion of employees from the American concept of corporate governance. ${ }^{57}$ Hence, all protective policies relating to investment regularly address the protection of the investor.

51. See the brilliant analysis by Katsuhito Iwai, Persons, Things and Corporations: The Corporate Personality Controversy and Comparative Corporate Governance, 47 AM. J. CoMP. L. 583 (1999). For a historical background and critique, see Paddy Ireland, Capitalism Without the Capitalist: The Joint Stock Company Share and the Emergence of the Modern Doctrine of Separate Corporate Personality, 17 J. Legal Hist. 41 (1996).

52. See generally A.J. Boyle, Minority Shareholders' Remedies (2002).

53. William Lazonick \& Mary O'Sullivan, Maximizing Shareholder Value: A New Ideology for Corporate Governance, in Corporate Governance and Sustainable Prosperity 11 (William Lazonick \& Mary O'Sullivan eds., 2002).

54. See Ronald J. Gilson, The Political Ecology of Takeovers: Thoughts on Harmonizing the European Corporate Governance Environment, in European Takeovers: Law and Practice 49 (Klaus J. Hopt \& Eddy Wymeersch eds., 1992).

55. Mark J. Roe, Path Dependence, Political Options, and Governance Systems, in Comparative Corporate Governance: Essays and Materials 165, 167-68 (Klaus J. Hopt \& Eddy Wymeersch eds., 1997); see also Mark J. Roe, Some Differences in Corporate Structure in Germany, Japan, and the United States, 102 Y ALE L.J. 1927 (1993).

56. See Margaret M. Blair, Ownership and Control: Rethinking Corporate Governance for the Twenty-first Century (1995).

57. John W. Cioffi, Corporate Governance Reform, Regulatory Politics, and the Foundations of Finance Capitalism in the United States and Germany 9 (Comp. Res. in L. \& Pol. Econ., Law Research Inst. Research Paper Series No. 6/2005, 2005) ("The American corporate governance regime embodies a complementary and mutually reinforcing relationship between the marketdriven financial system and a legalistic, transparency-based regulatory regime."), available at http:// www.comparativeresearch.net/papers/CLPE_Vol_01_No_01_RPS_06_Cioffi.pdf. 
With corporate law's mandate being driven and constantly refined by policy makers, regulators, and scholars, as well as leaders of business and industry associations, large corporations, public policy institutions, and regulatory bodies such as securities commissions, government commissions, and expert teams, as well as international financial institutions that promote goals of "good governance," the primary focus remains on the improvement of corporate disclosure and of more effective firm management. ${ }^{58}$

A final observation on the regulatory program of corporate governance is related to the world of corporate law scholarship and teaching. ${ }^{59}$ Corporate law as it is presented in textbooks and classrooms will usually exclude labor law, and hence, the employee. This, however, is owed less to an overriding sense of autonomy or even superiority as regards other fields than to the aim of corporate law teachers for a clear doctrinal and theoretical focus. To give an example: Bruce Welling writes in his influential casebook on Canadian corporate law: "[S]ome are outside the scope of 'corporate law' as such, having acquired a subspecialty over the years.... Some groups are not recognized in general as having a role to play in the corporation's government." ${ }^{60}$ In Robert Clark's masterful book, we find a clear reminder to his readers to include labor law in their research on corporations and corporate law. ${ }^{61}$ In contemporary writings, this diversity continues. In The Anatomy of Corporate Law, which has already become a leading reference work for the study of corporate law, the authors recognize labor law among other "non-corporate law constraints" imposed on companies. ${ }^{62}$ Labor

58. See generally Layna Mosley, Attempting Global Standards: National Governments, International Finance, and the IMF's Data Regime, 10 Rev. Int'L Pol. Econ. 331 (2003).

59. See generally Brian R. Cheffins, The Trajectory of (Corporate Law) Scholarship, 63 Cambridge L. J. 456 (2004).

60. Bruce Welling et al., Canadian Corporate Law 51 (2d ed. 2001).

61. Robert Charles Clark, Corporate Law 32 (1986) ("[E]ven if your aim is not to understand all of law's effects on corporate activities but only to grasp the basic legal 'constitution' or make-up of the modern corporation, you must, at the very least, also gain a working knowledge of labor law."); see also Detlev F. VaGts, Basic Corporation Law 11 (3d ed. 1989) (regretting the omission of labor and contract law from the reach of corporate law studies in spite of the fact that creditors and employees "may have a lasting and intimate relationship with the corporation"). A very careful assessment of the "dilemma" of the traditional definition of corporate law (to focus primarily on business associations and their organizational structure) is given by FrIEDRICH KübLER, GeselLschaftsrecht 3-4 (5th ed. 1998); a similarly cautious identification of the reach of corporate law-droit des affaires-is given by Yves Guyon, Droir des Affaires 1 (12th ed. 2003).

62. Reinier Kraakman et al., The Anatomy of Corporate Law: A Comparative and FuncTIONAL APProach 17 (2004). 
law, in this description, is identified as a body of law "designed to serve objectives that are largely unrelated to the core characteristics of the corporate form." ${ }^{63}$ In contrast, Simon Deakin, a British chaired corporate law professor and world-renowned labor law scholar observes: "While labour law and corporate governance could once have been thought as discrete areas for analysis, it is clear that this is no longer the case. The relationship between them has become both complex and paradoxical." ${ }^{\prime 4}$

This divergence in approaches and perspectives continues throughout the books written by corporate and labor law scholars, the journals they publish in, and the conferences they attend ${ }^{65}$ Within the academy and the law school's curriculum, corporate law is seen in concert with courses and issues in securities regulation and bankruptcy law, but not with labor law. Courses are not taught in reciprocal exchange of notes or literature, and students rarely take both—unless it is mandatory. We are reminded of the late Abram Chayes' astute observation: "The concept of Corporation has political, legal and social dimensions beyond the economic. But the appropriate academic disciplines remain largely unconcerned."

Before we widen this admittedly very narrow perspective to the regulatory context, a few introductory remarks shall be permitted with regard to the regulatory program of labor law.

\section{b. Labor Law}

Labor law's overriding concern is the protection of employment and employees. Its focus is on the employment contract, workplace safety, working hours, and minimum wages. Subsequently, its focus is on representation, whether on the firm level ("works councils") or in the context of collective bargaining. The historical and institutional memory of representation and conflict in labor law is long, and it clearly illuminates the painful trajectories of rights discovery, protection, and erosion through the rise of the industrial revolution

63. Id.

64. Simon Deakin, Workers, Finance and Democracy, in The Future of Labour Law: Liber Amicorum Bов Hepple QC 79, 79 (Catherine Barnard et al. eds., 2004).

65. But see, e.g., First International Conference of the Comparative Research in Law \& Political Economy Network at Osgoode Hall Law School, Toronto, Ontario, Can. (Oct. 20-21, 2005), http://www.comparativeresearch.net/main.php? page=events.php.

66. Abram Chayes, Introduction to John P. Davis, Corporations: A Study of the Origin and Development of Great Business Combinations and of Their Relation to the Authority of the State, at i (1961). 
and its ramifications and successors. ${ }^{67}$ In many accounts, labor law is today in crisis, and it remains far from clear whether a revival is in sight. ${ }^{68}$ At the same time, labor law and workers' rights are slowly becoming part of larger corporate social responsibility agendas. ${ }^{69}$ Much of this debate is concerned with placing the corporation in a greater social context. ${ }^{70}$ Where a wider perspective on the business corporation is taken, labor law meets employee-ownership theories, as well as stakeholder capitalism models. ${ }^{71}$

\section{The Regulatory Context of Corporate Governance and Labor Law}

\section{a. Corporate Governance}

With a view to the regulatory context in which we explore the purportedly separate worlds of corporate governance and labor law, we seek to trace the larger trends of ideology that shape both fields. We find global conversations about "best standards," universal norms, and a worldwide convergence toward one model of

67. See Achim Seifert, Das Recht der Arbeit im Wandel. Paradigmen des Arbeitsvertrags in der neueren Geschichte des deutschen Arbeitsrechts, in 5 Hannoversche Schriften: Transformation der Arbeit 153 (Detlev Claussen et al. eds., 2003); Harry W. Arthurs, Reinventing Labor Law for the Global Economy: The Benjamin Aaron Lecture, 22 Berkeley J. Emp. \& Lab. L. 271 (2001); Simon Deakin, Contract of Employment: A Study in Legal Evolution, Hist. Srud. Indus. ReL., Spring 2001, at 1.

68. See generally Weiss, supra note 31. But see H.W. Arthurs, National Traditions in Labor Law Scholarship: The Canadian Case, 23 Comp. LaB. L. \& PoL'y J. 645 (2002). For one of the most promising studies for future work, see generally Alain Supiot er al., Beyond Employment: Changes in Work and the Future of Labour Law in Europe (English language ed., Pamela Meadows et al. trans., Oxford Univ. Press 2001) (1999) (originally published in French, as AU-DELÀ DE L'EMPLOI: TRANSFORMATION DU TRAVAIL ET DEVENIR DU DROIT DU TRAVAIL EN EUROPE: RAPPORT POUR la Commission des communautés européennes, but rewritten in English to dispel "the impression that the analysis and diagnoses it contains apply mainly to France").

69. See, e.g., Wesley Cragg, Human Rights and Business Ethics: Fashioning a New Social Contract, 27 J. Bus. Etrics 205, 208 (2000); Andrew Gamble \& Gavin Kelly, Shareholder Value and the Stakeholder Debate in the UK, 9 Corp. Governance 110, 114 (2001); Steven R. Ratner, Corporations and Human Rights: A Theory of Legal Responsibility, 111 YaLE L.J. 443, 531-33 (2001). For a very critical stance, see H.J. Glasbeek, The Corporate Social Responsibility Movement-The Latest in Maginot Lines to Save Capitalism, 11 Dalhousie L.J. 363, 366-67 (1988).

70. See generally Alston, Core Labour Standards, supra note 19; Alston, Facing up, supra note 19, at 475-77; Blanpain \& Colucci, supra note 23, at 111-17; Robert O'Brien, The Difficult Birth of a Global Labour Movement, 7 Rev. INT'L PoL. Econ. 514 (2000).

71. See Gregory K. Dow, Governing the Firm: Workers' Conrrol in Theory and Practice (2003); Paul Edwards et al., New Forms of Work Organization in the Workplace: Transformative, Exploitative, or Limited and Controlled?, in Work and Employment Relations in the High Performance Workplace 72 (Gregor Murray et al. eds., 2002); Teresa Ghilarducci et al., Labour's Paradoxical Interests and the Evolution of Corporate Governance, 24 J.L. \& Soc'y 26 (1997). 
corporate governance. Clearly, we are entering endgames of Hegelian dimensions where we hear authors proclaiming the "end of history" with regard to the defeat of communism ${ }^{72}$ or the triumph of shareholder-value capitalism. ${ }^{73}$ Central to these discussions are national deadlocks over political conflicts resulting from path-dependent institutional structures and trajectories. ${ }^{74}$ Thus, it comes as no surprise that the existential differences between different corporate law regimes are regularly presented as the decisive challenge to law reform..$^{\text {is }}$

Corporate law in the United States, Canada, and the United Kingdom is overwhelmingly "enabling" law, with the state regulating only the framework and leaving the rest of the internal governance regulation to the firm's constitutional statutes. ${ }^{76}$ In contrast, while in the United States, Canada, and the United Kingdom only securities law is mandatory and federally regulated law, we find that company law regimes in Europe are much more regulated. For example, in Germany, most of corporate law is mandatory, not enabling, law. ${ }^{77}$ As already suggested in the introduction, however, the legislative framework of corporate law has ceased to be determined by domestic policy alone. And while this has occurred for several decades ${ }^{78}$ already, an even stronger push has taken place in the last few years. The making of corporate law is no longer only a domestic process

72. Francis Fukuyama, The End of History and the Last Man (1992).

73. Hansmann \& Kraakman, supra note 32.

74. See, e.g., Mark J. Roe, Political Foundations for Separating Ownership from Control, in Corporate Governance Regimes 113, 125-31 (Joseph A. McCahery et al. eds., 2002); see generally Ronald Dore et al., Varieties of Capitalism in the Twentieth Century, Oxford Rev. Econ. Pol'y, Winter 1999, at 102; Mark J. Roe, Commentary, Chaos and Evolution in Law and Economics, 109 Harv. L. Rev. 641, 643-44 (1996); Peer Zumbansen, European Corporate Law and National Divergences: The Case of Takeover Regulation, 3 Wash. U. Global Stud. L. Rev. 867, 881-82 (2004).

75. See, e.g., Ronald Dore, Stock Market Capitalism: Welfare Capitalism 176-81 (2000).

76. See Hansmann \& Kraakman, supra note 42; Joseph A. McCahery, Introduction to THE Governance of Close Corporations and Partnerships 1, 4 (Joseph A. McCahery et al. eds., 2004) ("A recurring theme in the literature concerns the role of mandatory rules in statutory standard forms. In contrast with the United States, the trend in European corporate law has been to dismiss the benefits associated with the enabling approach too quickly, relying on a narrow range of techniques and mandatory rules to balance the interests of the various parties.").

77. See Theodor Baums, Corporate Governance in Germany-System and Recent Developments, in Aspects of Corporate Governance 31 (Mats Isaksson \& Rolf Skog eds., 1994). But see Theodor Baums, Company Law Reform in Germany, 3 J. Corp. L. Stud. 181, 183 (2003) (discussing the "comply or explain" principle).

78. See Clive M. Schmitthoff, The Future of the European Company Law Scene, in The Harmonisation of European Company Law 3 (Clive M. Schmitthoff ed., 1973); Richard M. Buxbaum \& Klaus J. Hopt, Legal Harmonization and the Business Enterprise: Corporate and Capital Market Law Harmonization Policy in Europe and the U.S.A. 167 (1988). 
but one that unfolds in a multilevel environment of legislatures providing binding rules (e.g., the U.S. Sarbanes-Oxley Act of $2002 ; 7^{79}$ the refining listing rules for foreign corporations on the NYSE; ${ }^{80}$ the Organisation for Economic Cooperation and Development (OECD) Corporate Governance Principles and the OECD Guidelines for Multinational Corporations; ${ }^{81}$ and numerous corporate governance codes on the domestic, international, and transnational level ${ }^{82}$ ) and nation-state governments either transposing such norms or complementing them with further regulatory initiatives. This multilevel regulatory environment is characterized by a coexistence of soft norms generated by quasi-public expert commissions, ${ }^{83}$ hard, statutory law, and by cross-national benchmarking ${ }^{84}$ of standards and norms. It is in this context that the remarks by the EU Commissioner for the internal market, Charlie McCreevy, not to invest hopes in a soon-to-come EU-wide Code of Corporate Governance but, instead, to promote mutual learning and benchmarking, deserve particular attention:

Europe has a role to play. That role is to co-ordinate where possible Member States' efforts to improve corporate governance practices, through changes in their national company law, securities law or in corporate governance codes. There are different traditions in different Member States and those should be respected, but we must avoid unnecessary divergences which distort the single market and make life difficult for investors. Member States want and need to learn from each other's experience. The Corporate Governance Forum brings together a vast amount of high-level experience and expertise. It has a key strategic role to play. ${ }^{85}$

79. 15 U.S.C.S. $\$ \S 7201-7266$.

80. Jeffrey N. Gordon, What Enron Means for the Management and Control of the Modern Business Corporation: Some Initial Reflections, 69 U. CHI. L. Rev. 1233 (2002).

81. Orc. for Econ. Co-Operation and Dev., supra note 35; Org. for Econ. Co-Operation and Dev., The OECD Guidelines for Multinational Enterprises (2000), available at hitp:// www.oecd.org/dataoecd/56/36/1922428.pdf.

82. See generally Mallin, supra note 26, ch. 3; European Corp. Governance Inst., Index of All Codes, http:/www.ecgi.org/codes/all_codes.php.

83. See, e.g., Baums, supra note 34.

84. Zumbansen, supra note 27 , at 38.

85. Press Release, European Union, Corporate Governance: Commissioner McCreevy Outlines His Views to European Forum (Jan. 20, 2005), available at http:/europa.eu.int/rapid/ pressReleasesAction. do ? reference $=I P / 05 / 78 \&$ for $\mathrm{mat}=\mathrm{PDF} \&$ aged $=1$ \& language $=\mathrm{EN} \&$ guiLanguage $=$ en . 
In a more recent speech, delivered on November 17, 2005, McCreevy stressed the importance of this approach in light of the "different economic, social and legal traditions" among the EU Member States, even if he perceived a "market-driven trend towards convergence in Europe."

Not everyone, however, shares this careful and open perspective. No less than the "end of history" for corporate law was proclaimed, ${ }^{87}$ just before the financial scandals of Enron, WorldCom, Tyco, and others became public. ${ }^{88}$ The forceful and yet contested ${ }^{89}$ narrative of a worldwide turn to shareholder-value based rules of corporate governance was brought forward in light of the still vivid memories of the Takeover-High in the 1980s and 1990s, and the recovery of the U.S. economy and its citizens' buying power in a dazzlingly triumphant stock market. ${ }^{90}$ At its core, this narrative contains a powerful endorsement of the "outsider-control" model of corporate governance in which control is exercised through independent directors and through the stock market's scrutiny of management behavior through the threat of takeovers. In contrast, the story clearly marks as the losing party the "insider-model" of closely interconnected corporate holdings and seats on supervisory boards for financial institutions and industrial partners. ${ }^{91}$ The narrative has strong repercussions for the perception of the firm and, with it, the legal apparatus that is of relevance to the firm. Its

86. Charlie McCreevy, European Comm'r for Internal Mkt. \& Services, Future of the Company Law Action Plan (Nov. 17, 2005) ("There is no one-size-fits-all approach in corporate governance. The Commission should continue to encourage 'best practices' to develop according to the demands of ever more integrated markets."), available at http:/europa.eu.int/rapid/ pressReleases Action.do? reference $=\mathrm{SPEECH} / 05 / 702 \&$ for mat $=\mathrm{HTML} \&$ aged $=0 \&$ language $=$ EN\&guiLanguage $=$ en (last visited Dec. 23, 2005).

87. Hansmann \& Kraakman, supra note 32.

88. For a brilliant analysis of the Enron financial scandal, see William W. Bratton, Enron and the Dark Side of Shareholder Value, 76 TuL. L. REv. 1275 (2002).

89. See Branson, supra note 25; William W. Bratton \& Joseph A. McCahery, Comparative Corporate Governance and Barriers to Global Cross Reference, in Corporate Governance Regimes, supra note 74, at 23, 24; cf. Simon Deakin \& Alan Hughes, Comparative Corporate Governance: An Interdisciplinary Agenda, 24 J.L. \& Soc'y 1, 5 (1997) (providing examples of nations that do not have shareholder value-based models).

90. See Neil Fligstein, The Architecture of Markets: An Economic Sociology of TwentyFirst-Century Capitalist Societies 147-53 (2001).

91. See W. Carl Kester, Governance, Contracting, and Investment Horizons: A Look at Japan and Geimany, in Studies in International. Corporate Finance and Governance Systems: A Comparison of the U.S., Japan and Europe 227, 240-41 (Donald H. Chew ed., 1997); Klaus J. Hopt, The German Two-Tier Board (Aufsichtsrat): A German View on Corporate Governance, in CoMparative Corporate Governance: Essays and Materials, supta note 55, at 3, 12. 
strong emphasis on investor protection, financial transparency, and marketbased control mechanisms increasingly shifts emphasis away from modes of internal corporate control.

\section{Crisis, What Crisis?}

This is a crucial development. In the debate on the negative side of the account it leaves only generalizing umbrella terms that are employed to identify, but not explain, the insider-control model of corporate governance. The storyteller is thus inclined to forget certain characteristic features of the insider-control model that would be worth pondering for a better understanding of the process of corporate law evolution. The intimate relationship between corporate management and directors of lending institutions and CEOs of industrial partners in a densely woven corporate network-while clearly inducing many of the heavily criticized petrifying effects-clearly bears features of institutional stability and incremental growth. Among these forgotten features, we find long-term financing and the possibility of synergies in future-oriented research and development and innovation among connected firms. Furthermore, we find elements of variant forms of employee voice in the boardroom hidden under the insidercontrol terminology. Especially the latter has been declared as doomed, with regard to the inefficiencies associated with workers' participation in the boardroom and from the perspective of a property-rights-related assessment of the shareholder-value oriented firm. It seems clear from the point of view of a shareholders-as-corporate-owners model that workers ought not to be given a say in a corporate undertaking that is not theirs. ${ }^{92}$

This model, however, fails to conceive of the complexly structured entity of the publicly held, large business corporation. It has long been convincingly argued that a purely property-rights-based assessment of the corporation cannot adequately account for the role that is played by the corporation in society. ${ }^{93}$ From a labor law point of view and, more particularly, from an interest-pluralism point of view, the corporation's role is defined by the various social interests that come

92. See generally Mary O'Sullivan, The Innovative Enterprise and Corporate Governance, 24 CAMBRIDGE J. ECON. 393 (2000) (critiquing the shareholders-as-corporate-owners model); Paddy Ireland, Company Law and the Myth of Shareholder Ounership, 62 Mod. L. Rev. 32 (1999) (providing further critique of this model).

93. See Franz Kuein, Die neueren Entwicklungen in Verfassung und Recht der Aktiengesellscha ft (1904); Rathenau, supra note 33; Berle, supra note 33, at 18-19; Edward S. Mason, Introduction to The Corporation in Modern Society 1 (Edward S. Mason ed., 1961). 
together in its affairs. In this narrative, the corporation acts as a paradoxical instrument of domestication for powerful class conflicts. It is against this background that we must read narratives of industrial relations, workers' participation, and codetermination. These stories are, however, difficult to tell in times of economic recession and ever-more revelations of dark stains on the vest of "Germany Inc." 94 Most importantly, the volatile availability of global capital has induced an overwhelming pressure on corporate governance regimes worldwide to reform their regulatory framework to accommodate the institutional investors' interests. In that context, anything even remotely suspicious of protecting old-boys networks and opaque financial holdings arouses severe critique. Washed away, however, in this great spring cleaning, are ongoing attempts to further experiment with and build on schemes of representation and workers' voices in the corporation. It is no secret that the knowledge-based corporation is vitally dependent on the information input from its internal and external stakeholders (employees, research and development, universities, and research centers).${ }^{95}$ And yet, the current dominant narrative of corporate governance reform remains more than hesitant toward embracing more stakeholder-oriented assessments of the firm. ${ }^{96}$ Even less do we

94. See Dore, supra note 75, at 182-206. See generally Michel Albert, Capitalism vs. CapitalIsM (Paul Haviland trans., Four Walls Eight Windows 1993) (1991) (giving a very insightful account of Germany's particular corporate governance regime). Cioffi, supra note 57, at 10 (“A bank-centered financial system, networks of corporate cross-ownership, and interlocking boards stabilized financial and ownership relations within and among firms, freeing management to strategize for long-term growth. Strong labor unions and codetermination incorporated labor into economic and corporate governance in ways that further encouraged long-term planning and discouraged the pursuit of short-term financial returns. Overarching these arrangements, institutionalized bargaining among peak associations coordinated economic relations at the firm, sectoral, and national levels. The German corporate governance law channeled multiple contending stakeholder interests into largely self-regulating, long-term bargaining relationships.").

95. See The Knowledge Society: The Growing Impact of Scientific Knowledge in Social Relations (Gernot Bohme \& Nico Stehr eds., 1986); Bruno Amable et al., Les Systèmes d'innovation À l'ère de La globalisation (1997); Management in einer Welt der Globalisierung und Diversität: Europäische Und nordamerikanische Sichtweisen (Werner Auer-Rizzi et al. eds., 2002); Stefano Brusoni et al., Knowledge, Specialization, Organizational Coupling, and the Boundaries of the Firm: Why Do Firms Know More Than They Make?, 46 Admin. ScI. Q. 597 (2001).

96. See O'Sullivan, supra note 92. 
find active endorsements of the firm as a complex environment of societal experiment. ${ }^{97}$

Instead, current preoccupations in corporate law focus on management discretion to adopt takeover defenses without shareholder approval, ${ }^{98}$ on voluntary or legally mandated disclosure of management earnings, ${ }^{99}$ and on personal liability of company leaders for false information in securities markets. ${ }^{100}$ The financial scandals in the United States and elsewhere have not only sharpened the public's awareness of corporate greed but have more powerfully refreshed the image of the corporation from a shareholder-value point of view. The corporate governance crisis as a "crisis in confidence," which has been diagnosed since 2001 and has led to, among others, the Sarbanes-Oxley Act of August 2002, is the crisis as seen from within the shareholder-value paradigm. This crisis is an internal analysis of the law of corporate governance. And yet, the programs for crisis management fail to illuminate the fundamental complexity of regulating the firm as an innovative social actor.

In contrast, the corporate governance crisis as it is depicted by the erosion of employee power in corporations (German Mitbestimmung, unionism in Europe, the EU's Works Councils Directive, ${ }^{101}$ in North America, the shifting weight from collective bargaining to company level, flexibilized works council, "team

97. See, e.g., Gunther Teubner, "Corporate responsibility" als Problem der Unternehmensverfassung, 12 ZGR 34 (1983); Gunther Teubner, Enterprise Corporatism: New Industrial Policy and the 'Essence' of the Legal Person, 36 Am. J. Comp. L. 130 (1988); Peer Zumbansen, Innovation und Pfadabhängigkeit. Das Recht der Unternehmensverfassung in der Wissensgesellschaft [INnovation and Path-Dependency: The Constitution of the Firm in the Knowledge Society] (forthcoming 2006).

98. See Frank H. Easterbrook \& Daniel R. Fischel, The Proper Role of a Target's Management in Responding to a Tender Offer, 94 Harv. L. Rev. 1161 (1981); Silja Maul \& Athanasios Kouloridas, The Takeover Bids Directive, 5 German L.J. 355 (2004), http://www.germanlawjournal.com/pdf/ Vol05No04/PDF_Vol_05_No_04_355-366_Private_Maul_Kouloridas.pdf.

99. See Martin J. Conyon \& Kevin J. Murphy, Stock-Based Executive Compensation, in Corporate Governance Regimes, supia note 74, at 625, 640-41.

100. See Patrick S. Ryan, Understanding Director and Officer' Liability in Germany for Dissemination of False Information: Perspectives from an Outsider, 4 German L.J. 439 (2003), http://www. germanlawjournal.com/pdf/Vol04No05/PDF_Vol_04_No_05_439-475_Private_Ryan_ Complete.pdf.

101. Council Directive 2002/18, 2002 O.J. (L 80) 29 (EC). 
production, ${ }^{102}$ etc. $\left.{ }^{103}\right)$ is quite another. From the perspective of labor law, the corporation continues to be in crisis not (only) because of the robbery of shareholders by management but (importantly also) because of the continued division between the haves and have-nots. ${ }^{104}$ Robert Dahl's famous-infamous comparison between political democracy and corporate democracy continues to haunt the perennial strive for representation of employees within the corporation, a struggle that has already been fought many decades ago under the heading of "shareholder democracy" and the corporation as public actor. ${ }^{105}$

It is this undisclosed multiplication of images of the corporation and of its crisis that leads to the continued deadlocks in the untiring debate over the convergence of corporate governance standards. ${ }^{106}$ Crisis, what crisis? Joel Bakan's patient, the corporation, ${ }^{107}$ is, indeed, several patients in one. For Bakan, it is the pathological pursuit of profit, with the crudeness of exploitation and profit seeking, signifying the sickness of the patient. For those lamenting the loss of confidence in the capital markets (President Bush, declaring in the spring of 2001 the need for a yet unheard and unspecified corporate responsibility in contrast to the much debated corporate social responsibility), it is the need to install truly independent directors to keep the watch over self-interested (sic!) managers. However, another patient is the firm as painted with the brushes of labor law: the

102. Margaret M. Blair \& Lynn A. Stout, A Team Production Theory of Corporate Law, 85 VA. L. Rev. 247 (1999); Lawrence E. Mitchell, Trust and Team Production in Post-Capitalist Society, 24 J. Corp. L. 869 (1999).

103. See, e.g., Paul Edwards et al., supra note 71; Europäische Kommission, Final Report of the Group of Experts on European Systems of Workers Involvement (Davignon Report) (1997); Katharina Pistor, Codetermination: A Sociopolitical Model with Governance Externalities, in EMployees and Corporate Governance 163 (Margaret Blair \& Mark J. Roe eds., 1999); Rüdiger Krause, Sarbanes-Oxley Act und deutsche Mitbestimmung, WertPaPiermitTEILUngen [WM] 762 (2003); John Parkinson, Models of the Company and the Employment Relationship, 41 BRIT. J. INDUs. REL. 481 (2003).

104. Marc Galanter, Why the "Haves" Come out Ahead: Speculations on the Limits of Legal Change, 9 L. \& Soc'y Rev, 95 (1974).

105. See, e.g., Rathenau, supra note 33. See Paddy Ireland, History, Critical Legal Studies and the Mysterious Disappearance of Capitalism, 65 Mod. L. Rev. 120 (2002).

106. See, e.g., Henry Hansmann \& Reinier Kraakman, Toward a Single Model of Corporate Law?, in Corporate Governance Regimes, supra note 74, at 56; Ronald J. Gilson, Globalizing Corporate Governance: Convergence of Form or Function?, 49 AM. J. Comp. L. 329 (2001); Carsten Berrar, Die Entwicklung der Corporate Governance in Deutschland im internationalen Vergleich (2001); Mathias M. Siems, Die Konvergenz der Rechtssysteme im Recht der Aktion$\ddot{A} R E$ (2005).

107. Joel Bakan, The Corporation: The Pathological Pursuit of Profit and Power (2004). 
utopia of a just society produces many angels and demons, and it remains unclear into which category the corporation falls. But the hospital ward for labor law patients is likely to be closed in the near future.

\section{Discourses on Nature are Discourses on Form and Substance}

The substantive debate over the "nature of the firm"108 imperceptibly moves into the realm of law making when we discuss the law of corporate governance (or of labor law) in the context of the increasing proliferation of codes of conduct. However, the debate over the genesis and validity of soft law has been, as we will see when we turn to current developments in the International Labour Organization (ILO) and in public international law, kept quite distinct from the substantive debate over the corporation's role in society. This is surprising, as the fierce battle over the public-private nature of codes of conduct, raised as regards their creation and enforceability, is so obviously a mirror image of the public-private nature of the corporation itself. But the "codes movement" is seen as a mere spin-off of a larger trend of corporate law autonomization, weakening the tight grasp of political regulation as firms escape the nation-state's regulatory grip.

From the perspective of the corporation's stakeholders, corporate governance codes can be understood as managing (or circumventing) the representation of employees in supervisory committees, the size of supervisory committees, and the frequency of meetings. Expanding this perspective, "good corporate governance," as understood by the International Monetary Fund (IMF), the World Bank, and the OECD, consists of optimal levels of investor protection through strict disclosure rules, effective control mechanisms, and the mitigation or elimination of worker involvement in the running of the company. ${ }^{109}$ Good corporate governance becomes part of a more generally conceived measure of "good governance." The worker who is lost in the current paradigm of corporate governance, however, is unlikely to be rediscovered in the "good governance" and structural adjustment programs put forward by international financial institutions. ${ }^{110}$ It is

108. See generally Ronald Coase, The Nature of the Firm, 4 Economica 386 (1937).

109. See World BANK, supra note 43, at 58, 63-64; Arthurs, supra note 67, at 284-85; KerRY Rittich, Vulnerability at Work: Legal and Policy Issues in the New Economy: Report for the Law Commission of Canada 26, 40-41 (2004), available at http://www.lcc.gc.ca/pdf/ rittich.pdf. For the context of such eroding labor rights, see Ritтich, supra, at 9-11.

110. See, e.g., Antony Anghie, International Financial Institutions, in The Politics of INternational Law 217 (Christian Reus-Smit ed., 2004); Kerry Rittich, Recharacterizing Restructuring: Law, Distribution and Gender in Market Reform (2002). 
against this background that we need to take a closer look at the transformations that define the current regulatory context of labor law.

\section{b. Labor Law}

Labor law's legislative and larger regulatory program has been defined by statutory law, case law, and soft law of both transnational and domestic origin. As regards labor law litigation, classically, we find examples of highly politicized adjudication, often greatly dependent on the presiding judges of highest labor courts. ${ }^{111}$ Labor law norms and rights are shaped through case law and statutory law, but with the persisting difficulties of ratifying international labor law conventions by the ILO, founded in 1919, emphasis and hope for a more effective regulation of corporate conduct increasingly are being placed on corporate codes of conduct and on transnational concepts such as "core labor rights." Like the law of corporate governance, labor law has long come under the influence of transnational norms, the ILO conventions being among the most commonly known.

It can be said that transnational labor law evolves also where no explicit, formal ratification of norms has taken place in the Member States. This is owed to the fact that labor law standards and policy considerations transgress geographical and political borders and thereby contribute to elements of what Harry Arthurs referred to as a "Labour Law Without the State." 112 This body or, more accurately, this web of transnational norms and standards, consists of norms generated by international organizations, such as the ILO, and of private norms issued by corporate actors and interest organizations. ${ }^{113}$ Labor norms included in corporate codes of conduct raise dramatic questions as to the scope and limits of protection that they offer. ${ }^{114}$ This coexistence and overlapping of public and private regulation, and of norm generation among states and private actors, illustrates what Philip Jessup coined "Transnational Law,"115 and what others have identified as the "self-regulation of transnational civil society." 116

111. For example, in Germany, labor law's development is regularly attributed to the changing presidents of the Federal Labor Court.

112. Arthurs, supra note 31.

113. See, e.g., Corporate Codes of Conduct, http://www.itcilo.it/english/actrav/telearn/global/ilo/ code/main.htm (last visited Jan. 13, 2006).

114. Blackett, supra note 16; Harry Arthurs, Private Ordering and Workers' Rights in the Global Economy: Corporate Codes of Conduct as a Regime of Labour Market Regulation, in LABour LAw in an Era of Globalization, supra note 30, at 471.

115. Philip C. Jessup, Transnational Law (1956); see Zumbansen, supra note 47.

116. Robé, supra note 48 , at $45,49$. 
With the legislative nature and quality of the ILO thus remaining a challenge, it is worthwhile to reflect on the evolution and mandate of the ILO. The ILO's history of attempts to create worldwide labor rights to protect workers had already begun by the end of the nineteenth century. In fact, the ILO's very creation gives strong testimony of institutional commitment and its drive toward international cooperation. The ILO's subsequent dramatic history reaches a high point with the 1998 Declaration of the Fundamental Principles and Rights at Work (1998 Declaration) that proclaims four core principles: (1) freedom of association and effective recognition of the right to collective bargaining, (2) protection against forced labor, (3) elimination of child labor, and (4) freedom from discrimination. ${ }^{117}$ While the 1998 Declaration marks a long-needed institutional and theoretical reaction to the challenge presented to labor law, and its norms and institutions through the rise of the network society and the knowledge-based global economy, ${ }^{118}$ the 1998 Declaration marks, at the same time, a veritable "constitutional moment" in international labor law. ${ }^{119}$ The 1998 Declaration moves into bright light the long-standing challenges to the ILO's tripartite structure (states, employers, unions) in terms of effective negotiation and enforcement of its norms- which can be done only by way of ratification. After recalling the origins and founding principles of the organization, the $1998 \mathrm{Dec}-$ laration states:

[A]ll Members, even if they have not ratified the Conventions in question, have an obligation arising from the very fact of membership in the Organization to respect, to promote and to realize, in good faith and in accordance with the Constitution, the principles concerning the fundamental rights which are the subject of those Conventions. ${ }^{120}$

117. See ILO Declaration on Fundamental Principles and Rights at Work, June 18, 1998, 37 I.L.M. 1233 (1998), available at http://www.ilo.org/dyn/declaris/DECLARATIONWEB. INDEXPAGE; Langille, supra note 19, at 415.

118. Arthurs, supra note 67.

119. See Francis Maupain, Revitalization Not Retreat: The Real Potential of the 1998 ILO Declaration for the Universal Protection of Workers' Rights, 16 EUR. J. INT'L L. 439, 441 (2005) (“[T]he Declaration is probably the most significant of the various normative developments that had taken place over the last decade.").

120. ILO Declaration on Fundamental Principles and Rights at Work, supra note 117. 
These four principles lie at the heart of the debate over the future prospects of international labor law, but this debate touches upon the foundations of labor law as such. ${ }^{121}$

As a consequence, the theme "Globalization and Labor Law" can be told as two narratives: one is the story of exhaustion, the other the story of an emerging new legal order. The story of exhaustion includes the creation of the ILO and its long and often painful history of bringing opposing nations to the bargaining table to sign conventions on workers' rights, which they then had to ratify in their domestic parliaments. While the Cold War made for little progress in the ILO, as the command and control structure in communist countries undermined the purpose of the ILO's unique tripartite structure, the ILO has been facing another challenge in recent years. With a steady decline in union density and relevance, unions might no longer be the adequate mouthpieces for a globally dispersed workforce. Meanwhile, the representative void is increasingly claimed by NGOs, but the following concerns arise: (1) the ILO fears more chaos for the already difficult negotiations, (2) the unions fear chaotic trends of interest representation and that NGOs will import many heterogeneous issues that are not altogether related to labor questions, while (3) the NGOs fear to give up much of their institutional independence and autonomy when integrated into the ILO's formal negotiation structure.

The second law-making-related narrative begins where the institutional story of the ILO allegedly ends, and it is here where the problem lies. Very briefly, the ILO's 1998 Declaration could mark a turning point for the organization, dispelling a lingering existence of often ineffective convention making with few concrete results or effect. Through the 1998 Declaration, the ILO has installed a multiparty monitoring and cooperation program, which is supposed to create a powerful new solidarity program with a practically effective side to it: countries shall work closely together when importing a convention into domestic law. As the agenda foresees a long-term engagement, it follows that the ILO and respective nations will work closely together to find a solution adequate to the actual conditions in a given country.

121. Alston, Core Labour Standards, supra note 19; Langille, supra note 19; Alston, Facing up, supra note 19. 


\section{B. The Political Economy of Regulation}

\section{The Exhaustion of the State as Regulator}

It is against this multilayered background that we need to reflect on the potential directions that law making in corporate governance and labor law might take in the future. What is particularly striking about the developments in both fields is their parallelism regarding the transformation of the forms of norm generation, norm dissemination, and norm enforcement. In both fields, we see the emergence of norms that are no longer generated only by officially recognized sources of law, but also by a multitude of domestic, foreign, and transnational norm producers. These soft norms constitute a radical challenge to the state-based concept of law making that began to emerge in the nineteenth century and that Max Weber, among others, ${ }^{122}$ has so powerfully captured as the rise of "modern law." 123 In contrast to law originating in an official constitutional order, soft law encompasses norms that are not attributable to an official author of statutory norms, and which do not appear directly enforceable by recognized, traditional means for the execution and application of legal rules. Instead, the soft law of both corporate governance and labor law (the latter being enshrined particularly in corporate codes of conduct and in core labor standards) can be read as reactions against incapacities on the part of the state to proceed with adequate legislation. The proliferation of soft law in corporate governance and in labor law thus offers examples of what anthropologists and legal sociologists have described as "legal pluralism." 24 It consists of expert standards, best practices, recommendations, and principles, as well as standards, that can be seen to inform ongoing searches for "better law" without due regard to political or geo-

122. See Eugen Ehrlich, Fundamental Principals of the Sociology of Law 10-23 (Walter L. Moll trans., Harv. U. Press 1936) (1929).

123. See Max Weber, Economy and Society: An Outline of Interpretive Sociology 880-92 (Ephraim Fischoff et al. trans., Bedminster Press 1968) (1914).

124. See Moore, supra note 47; Harry W. Arthurs, Without the Law: Administrative Justice and Legal Pluralism in Nineteenth Century England 50-88 (1988) (describing the persistence of legal pluralism in light of the ever stronger tendencies to centralize law through statutory law and official courts); see generally John Griffiths, What is Legal Pluralism?, 24 J. LeGal PluralISM \& U NOFFicial L. 1 (1986) (defining “legal pluralism"). For further assessments of legal pluralism, see Teubner, supra note 47, and Oren Perez, Normative Creativity and Global Legal Pluralism: Reflections on the Democratic Critique of Transnational Law, Ind. J. Global Legal Stud., Summer 2003 , at 25 . 
graphical borders. Jill Murray, a long-time expert on the ILO and on transnational labor law, powerfully captures this phenomenon:

There was a time when a student of labor law could expect to be introduced to three elements of the discipline: the study of "us," the national labour law and institutions of the particular country in which the course is located, the study of "them," comparative studies of the national laws and institutions of other countries, and the study of the "international," usually confined to a consideration of the role and function of the International Labour Organisation (ILO).... Of course, beneath these comfortable divisions there was always a flow of influence and ideas about labour regulation both between national boundaries, and between nation states and the international body. Although the study of comparative law has become increasingly sophisticated, very little has been said about these interconnections between the spheres of "domestic" and "international" in relation to the regulation of labour relations. In any event, this implied clear division between national and international, and the identity of these two spheres on which the distinction was based, is no longer a central organising principle within the discipline of labor law. ${ }^{125}$

Bob Hepple, a grand doyen of labor law, uses the term "privatising regulation" to describe the phenomenon of fragmented labor law norm creation. ${ }^{126}$ "The most striking feature of current attempts to build on the attempts of TNC [transnational corporations] is fragmentation." 127 The proliferation of normgenerating institutions and entities has received extensive theoretical analysis in the last three decades, ${ }^{128}$ but much more must be done to further illuminate the separate worlds of corporate governance codes and corporate codes of conduct regarding, on the one hand, their common origin in strained regulatory powers

125. Jill Murray, Book Review, 30 Indus. L.J. 246, 246-47 (2001) (reviewing John Braithwaite \& Peter Drahos, Global Business Regulation (2000) and Regulating International Business: Beyond Liberalization (Sol Picciotto \& Ruth Mayne eds., 1999)).

126. HePple, supra note 13 , at $69-87$.

127. Id. at 69.

128. See, e.g., Global Law Without a State, supra note 47. 
of domestic and international legislators and, on the other, their apparently different political agenda.

The emergence of this unique and yet highly fragmented and decentralized body of norms challenges our traditional state-based understanding of law making, and thus provides a common ground on which to assess the emergence of privatized corporate law regimes, ${ }^{129}$ corporate codes of conduct, and core labor rights. That these forms of soft law in both fields cannot, however, betray their stark differences with regard to their underlying policy agendas becomes clear when we focus on their larger programmatic aspirations.

\section{Corporate Governance Codes}

Corporate governance codes produced by national expert commissions or other large, national entities such as industry associations or corporations often embody condensed versions of the country's larger body of statutory norms alongside recommendations that are intended to make corporate management more responsible to investor interests. ${ }^{130}$ While condensed norms are included in codes to facilitate the navigation of foreign investors through a complex web of applicable rules, the recommendations are usually meant to appeal to the management as regards the attainment of effective management practices, financial transparency, and responsiveness to shareholder interests. ${ }^{131}$ The formulation and dissemination of corporate governance codes have dramatically increased over the past ten years, and the reasons for this development are to be sought particularly in the increased need for domestic corporations to attract foreign capital flows. As financial flows became ever more volatile, flexible, and mobile, the need for an increasingly investor-friendly regulatory environment began to be acknowledged even where firm traditions of bank-based, long-term financing made domestic law and policy makers take a rather skeptical or defensive attitude. ${ }^{132}$ Certainly, the emergence of corporate governance codes, as it speaks to the increased frequency of supervisory board meetings or, to take another issue that today is ardently disputed, the amount and the disclosure of management

129. Zumbansen, supra note 27.

130. See, e.g., Baums, supra note 34 (the "inside account" by the former chair of Germany's first government commission to analyze the shortcomings in the existing corporate law rules and to prepare recommendations directed at management and shareholders).

131. For an in-depth study of current corporate governance codes, see ZuMBANSEN, supra note 97.

132. See John W. Cioffi, Restructuring "Germany Inc.": The Politics of Corporate Governance Reform in Germany and the European Union, 24 L. \& PoL'y 355 (2002); C1OFF1, supra note 57. 
earnings, ${ }^{133}$ must be seen as potentially powerful remedies against regulatory deadlocks and blockades in bargaining games on the political floor. ${ }^{134}$ In light of long-standing lines of political confrontation with regard to key elements of corporate governance, the inclusion of recommendations and best practice guidelines in corporate governance codes might prove an effective tool. ${ }^{135}$

But, there should also be no doubt as to the long-term consequences of this form of soft law. One example shall suffice: the German corporate governance code, prepared by a government commission of German lawyers, bankers, and business experts, endorses separate preparatory meetings of the shareholder representatives on the supervisory board as best practice. The underlying justification is that important decisions should be prepared among the shareholder representatives so as to be presented more convincingly to the employee representatives at the official plenary meeting. The crux of the code's recommendation, however, must be seen in the fact that such separate meetings have been practiced all along, despite the persistence of the criticism that they effectively undermined the aims of workers' codetermination in supervisory boards. With the inclusion of a recommendation of separate preparatory meetings in the code, this practice is effectively endorsed as an example of "good corporate governance."

\section{Corporate Codes of Conduct}

In contrast, corporate codes of conduct, while escaping any straightforward attempt at definition, regularly contain a number of ethical standards for corporate officers' conduct with regard to the workforce (and usually the environ-

133. See generally Brian R. Cheffins, The Metamorphosis of "Germany Inc. ": The Case of Executive Pay, 49 Aм. J. Comp. L. 497 (2002) (discussing the Americanization of corporate governance in Germany); Alain Alcouffe \& Christiane Alcouffe, Control and Executive Compensation in Large French Companies, 24 J.L. Soc'y 85 (1997) (examining increases in executive pay in French firms); Lucian Bebchuk \& Jesse Fried, Pay Without Performance: The Unfulfilled Promise of Executive Compensation (2004) (arguing for increased attention to the problem of excessive executive pay); see also Conyon \& Murphy, supra note 99, at 625-46; For critiques, see William W. Bratton, The Academic Tournament over Executive Compensation, 93 CaL. L. Rev. 1557 (2005) (book review); James McConvill, Positive Corporate Governance and Its Implications for Executive Compensation, 6 German L.J. 1777 (2005).

134. See Martin Höpner, European Corporate Governance Reform and the German Party Paradox (Max-Plank-Institut für Gesellschaftsforschung Discussion Paper 03/4, 2003), available at http://www.mpi-fg-koeln.mpg.de/pu/mpifg_dp/dp03-4.pdf.

135. For a discussion of the contribution of corporate governance codes to the (improved) selfregulation of corporations, see Zumbansen, supra note 97 , ch. 3. 
ment). ${ }^{136}$ They too can be seen as emerging in the absence of tangible and effective regulation for a dramatically deregulated work place reality. And yet, the emergence of corporate codes of conduct is driven by an actor, or a combination of actors, quite distinct from the one that informs the creation of corporate governance codes. From one perspective, corporate codes of conduct could be seen, in many ways, as the result of a unique form of public protest in a transnational civil society. The scandalizing of human rights abuses brought to attention by NGOs, social and political activists, or the press has drastically reduced the distance between these events and an increasingly disturbed public in formerly faraway places. Consumer protest, public incrimination or the initiation of protests, strikes by labor activists, and the branding of abusive corporate practices by various civil society members ${ }^{137}$ seems to be the labor-law-related equivalent to the recently described phenomenon of an emerging transnational human rights regime. ${ }^{138}$

Strikingly, however, these parallels are not yet fully realized. ${ }^{139}$ Alongside vivid attempts by international organizations such as the OECD and the ILO to promote a more effective observance of fundamental employee rights by corporations, corporations have produced corporate codes of conduct that include nu-

136. Charles Sabel, Dara O'Rourke and Archon Fung have written several papers about corporate "codes of conduct." Charles Sabel, Dara O'Rourke \& Archon Fung, Ratcheting Labor Standards: Regulation for Continuous Improvement in the Global Workplace (World Bank, Social Protection Discussion Paper Series No. 0011, 2000), available at http// siteresources.worldbank.org/SOCIALPROTECTION/Resources/SP-Discussion-papers/LaborMarket-DP/0011.pdf; Charles Sabel et al., Ratcheting Labor Standards: How Open Competition Can Save Ethical Sourcing, in Visions of Ethical Sourcing: A Series of Free Vision Papers (Raj Thametheram ed. 2001), available at http:/www2.law.columbia.edu/sabel/papers/fintimes.pdf; Charles Sabel et al., Open Labor Standards: Toward a System of Rolling Rule Regulation of Labor Practices (discussion paper for the Annual Meetings of the World Bank Seminar on Labor Standards on Sept. 28, 1999), available at http:/www2.law.columbia.edu/sabel/papers/ ols.pdf. For a very insightful discussion of this proposal, see Adelle Blackett, Codes of Corporate Conduct and the Labour Regulatory State in Developing Countries, in Hard Choices, Soft Law: Voluntary Standards in Global Trade, Environment and Social Governance 121 (John J. Kirton \& Michael J. Trebilcock eds., 2004).

137. Robert Wai, Countering, Branding, Dealing: Using Economic and Social Rights in and Around the International Trade Regime, 14 Eur. J. INT'L L. 35, 73-76 (2003).

138. See Craig Scott \& Robert Wai, Transnational Governance of Corporate Conduct Through the Migration of Human Rights Norms: The Potential Contribution of Transnational 'Private' Litigation, in Transnational Governance and Constitutionalism 287 (Christian Joerges et al. eds., 2004); Zumbansen, supra note 39.

139. "The international human rights movement has, until recently, paid relatively little attention to workers' rights." HePple, supra note 13, at 21. 
merous pledges and voluntary commitments by the corporation to adhere to the self-prescribed standards. ${ }^{140}$ Their legal quality is hard to assess-they are as yet considered nonlegal, unenforceable, and predominantly voluntary self-imposed obligations. ${ }^{141}$ They raise important questions as to the scope of protection they effectively offer and the larger regulatory trend in protecting labor rights that they could be seen to drive forward. "Private corporate codes exist because of the absence of an enforceable internationally agreed labour regime." 142 Thus, while it can be hoped that they attain some prominence through continued pressure from civil society, as well as from such organizations as the ILO and the OECD, which have undertaken extensive studies of numerous corporate codes of conduct, ${ }^{1+3}$ a number of fundamental problems remain. As voluntary codes of conduct, they remain in the sole discretion of the corporation; they are often not the product of a negotiation between employer and employees. ${ }^{144}$ Crucially, perhaps, corporate codes of conduct embrace company-level regulation of work-related issues while often rejecting union involvement or other forms of organized worker representation. As such, voluntary codes bear the danger of cutting the ties between the worker and the outside system of institutional safeguards.

These last observations complement the already touched upon changes in the regulatory framework of labor law. To cite Adelle Blackett,

Contemporary initiatives for setting soft law standards for labour must take into account the specificity of labour regulation, at both the national and international levels. Despite their apparent pragmatic potential to improve often deplorable conditions, such initiatives on labour are deeply called into question. Labour is a field once largely filled by a dense combination of industrial relations

140. See, e.g., Org. for Econ. Co-Operation and Dev., The Implementation of the OECD Guidelines for Multinational Enterprises and the Functioning of National Contact Points (2002), available at http://www.olis.oecd.org/olis/2002doc.nsf/ (follow "Reference Components" hyperlink; then click on the blue arrow to the left of "PAC (PUBLIC AFFAIRS AND COMMUNICATIONS DIRECTORATE)"; then click on the blue arrow to the left of "PAC/ AFF/LMP"; then follow the "PAC/AFF/LMP(2002)10" hyperlink; and finally click on whichever flag-patterned document icon corresponds to your preferred language and document type).

141. "What [most private codes] share in common is that they are voluntary written commitments to observe certain standards in the conduct of business." Hepple, supra note 13, at 73.

142. Id. at 72 .

143. Id.

144. Arthurs, supra note 114. 
regulatory machinery at the domestic level, particularly in states that espoused embedded liberalism, and a plethora of international labour standards, meant largely to guide the creation and strengthening of state labour regulatory power. ${ }^{145}$

The emergence of codes of conduct must thus be seen as part of what is a much more complex phenomenon. Different attempts to define, categorize, and qualify corporate codes of conduct can only result in highlighting all those questions that are connected to the issues of voluntariness, nonenforcement, minimum standards, and self-commitment. To adequately unfold the many dimensions of the phenomenon of private law making, we must reach beyond this straightforward, legalistic inquiry into the legal and nonlegal nature of voluntary codes. Where we focus on soft law, core labor rights, and the alleged privatization of the labor-law-making process, we are bound to take a decisively negative viewpoint on the contemporary regulatory landscape. ${ }^{146}$ The alternative perspective would be more realistic. ${ }^{147}$ What this inquiry could lead to, eventually, would be a renewal of those normative promises that informed labor law from its beginnings, while reconstructing them in view of the changes in the regulatory environment as they have been described. A juxtaposition of the allegedly private vices of voluntary codes of conduct with the public virtues of an effectively functioning, protective labor law regime can be validated only in this regard. Where it helps to initiate renewed deliberations over the protective scope of labor law norms, instead of condemning all forms of soft law outright, the juxtaposition of private and public ordering could allow us to illuminate the shortcomings and preoccupations on both sides.

\section{Public Versus Private Regulation: Can Globalization Be "Fair"?}

In order to further assess the regulatory environment in which we see the emergence of corporate codes of conduct, we need to widen the perspective still more. In February 2004, the World Commission for the Social Dimension of Globalization issued a 190-page report, "A Fair Globalization: Creating Oppor-

145. Blackett, supra note 136, at 121 .

146. See Alston, Core Labour Standards, supra note 19, at 458; Philip Alston \& James Heenan, Shrinking the International Labor Code: An Unintended Consequence of the 1998 ILO Declaration on Fundamental Principles and Rights at Work?, 36 N.Y.U. J. INT'L L. \& PoL. 221, 224 (2004).

147. See Langille, supra note 19 , at 409-12. 
tunities for All." 148 The Commission was initiated by the ILO in 2002 and produced a wide-ranging analysis as well as recommendations on globalization's much-disputed "discontents," such as poverty, inequality, and exclusion. ${ }^{1+9}$ While the report embraces highly advanced ideas of decentralized law making and responsive regulation, some authors recognize that risks lie in focusing on the promotion of labor standards while decoupling this process from the existing law-making and supervisory mechanisms in the ILO. ${ }^{150}$ Their intention to instead preserve a strong role for the tripartite negotiation framework at the ILO could invite equal amounts of critique and applause. The problem, however, lies elsewhere. No adequate assessment of the regulatory models as suggested in the Commission's report is possible when the substantive discussion over the need for an effective labor law regime is decoupled from the wider range of regulatory changes that characterize the attempts to consolidate and protect rights of workers in a globally integrated marketplace. Namely, seen in light of current regulatory changes in labor law making that are defined by a seemingly irreversible trend to company level negotiation and minimum standards, the report's authors went to great lengths in defining their approach to addressing the regulatory challenge that labor law faces today. The Commission can in fact be seen as embracing a decentralized and highly diversified public-private policy mix. As such, the report cannot be imagined without keeping in mind prior experiences with the United Nations Global Compact ${ }^{151}$ and the more recent Draft Norms on Human Rights Responsibilities for Transnational Corporations. ${ }^{152}$

148. World Comm'n on the Soc. Dimension of Globalization, A Fair Globalization: Creating Opportunities for Alt (2004), available at http://www.ilo.org/public/english/wcsdg/docs/ report.pdf.

149. Sassen, supra note 16; Joseph E. Stiglitz, Globalization and Its Discontents (2002).

150. See generally Alston \& Heenan, supra note 146.

151. The U.N. Global Compact was initiated in 1998 by U.N. Secretary General, Kofi Annan, to create an international initiative that would bring companies together with U.N. agencies, labor, and civil society to support universal environmental and social principles. See United Nations Global Compact Home Page, http://www.unglobalcompact.org (last visited Jan. 13, 2006). For a discussion, in particular, of its voluntary, non-binding nature, see Sean D. Murphy, Taking Multinational Corporate Codes of Conduct to The Next Level, 43 Colum. J. Transnat'l L. 389, 411-13 (2005).

152. See generally Carolin F. Hillemanns, UN Norms on the Responsibilities of Transnational Corporations and Other Business Enterprises with Regard to Human Rights, 4 GERMAn L.J. 1065 (2003), http://www.germanlawjournal.com/pdf/Vol04No10/PDF_Vol_04_No_10_1065-1080_ European_Hillemanns.pdf (discussing the development of guidelines for corporations with regard to human rights and labor rights). 
When compared to developments in regulatory regimes elsewhere, we are increasingly able to understand the similarity between the rights protection regime in labor law and other areas of globalized law. ${ }^{153} \mathrm{We}$ find that problems of procedure, norm generation, and enforcement must be seen in close connection to the substantive area in which they are developed. It is only when these different dimensions are conflated that ideology can make us blind to the complexity of the challenge. ${ }^{154}$ Even the most dedicated labor lawyers express their positive (or perhaps optimistic) expectations toward the current development in transnational labor law making. ${ }^{155}$ But, they also point to the dramatic risks inherent in this process: without long-term-oriented institution building, workers as vulnerable contract partners might before long become subjected to market forces without any effective defense instruments to aid them.

\section{Legal Rhetoric and the Move Away from Formalism}

What remains crucial is the assessment of times and places when and where a certain legal program is being promoted and the rhetoric that is being employed to that effect. Law making never takes place in a void. Instead, the tension that we can perceive in the area of international labor law between state regulation and monitoring, on the one hand, and soft law, core labor rights, and corporate self-regulation, on the other, can be seen as resonating with a much larger trend in contemporary international legal thinking. As Martti Koskenniemi brilliantly argued, the current state of theorizing in international law-in particular on the issue of humanitarian intervention and the "war against terror"-is characterized by a "turn to ethics" and an ironic reversal of the normal and the exception. ${ }^{156} \mathrm{We}$ tend to disregard the normal and to take it as given, natural, and ultimately neutral. Only the exception challenges us, and only in mobilizing an ethical response to the perceived horrors of the world do we proclaim universal standards and solidarity. We intervene in other countries based on a very vaguely defined ethical agenda and thereby forget the everyday

153. For an explanation of globalization and its effect on administrative law, see Alfred C. Aman, Jr., Administrative Law for a New Century, in The Province of Administrative Law 90 (Michael Taggart ed., 1997); Alfred C. Aman, Jr., The Democracy Deficit (2004).

154. For an exposition of the role of ideology in informing our description and mobilization of legal regimes, see Susan Marks, The Riddle of All Constitutions 8-29 (2000).

155. See Weiss, supra note 31, at 177; Arthurs, supra note 67, at 285; Langille, supra note 19, at 437. 156. Martti Koskenniemi, 'The Lady Doth Protest Too Much': Kosovo, and the Turn to Ethics in International Law, 65 Mod. L. Rev. 159, 160 (2002). 
injustice that has always been and to the continuance of which we greatly contribute. $^{157}$

One finds it hard to dissociate this observation from assessments of the developments in international economic law, the WTO, the World Bank, and the IMF. In both general public international law and international economic law we appear to be facing erosions of formalism. ${ }^{158}$ Instead, we find policy agendas that cover macro- and microeconomic adjustment as conditions for funds and loans. ${ }^{159}$ This development is largely principle and policy driven, and it functions-to a large degree-without formal rules. Almost imperceptibly, the global marketplace begins to represent elements of a political "New World Order." ${ }^{160}$ But, while its protagonists aspire to the transnational emergence of networks and civil society bodies engaging in global deliberations, ${ }^{161}$ the new world order could elevate the struggle over political values to an abstract level where decisions are taken over liberal and non-liberal states, good states and rogue states. An ethical turn could dissociate decision-making processes from any procedural critique of how this process is composed and into which larger regimes of law creation, law enforcement, and power distribution it is embedded.

\section{The Emergence of Transnational Law}

\section{A. The Transnational Advantage}

It is here that we need to contemplate the particular quality and role of law in this process today. Our previous examination of the actors and decentralized law making processes enables us to take a closer look at current forms of multilevel and multipolar regulatory governance. As suggested above, the norms that

157. The theme of law's violence is, of course, a very old one and one that is inherent to law. See Douglas Hay, Time, Inequality, and Law's Violence, in LAw's VIOLENCE 141, 141-73 (Austin Sarat \& Thomas R. Kearns eds., 1992).

158. Rittich, supra note 109, at 153-69.

159. Anghie, supra note 110 , at 224. See also STiglitz, supra note 149, at 27-28.

160. AnNe-Marie Slaughter, A New World Order (2004).

161. See Anne-Marie Slaughter, The Real New World Order, Foreign Afr., Sept.-Oct. 1997, at 183, 184 ("A new world order is emerging, with less fanfare but more substance than either the liberal internationalist or new medievalist visions. The state is not disappearing, it is disaggregating into its separate, functionally distinct parts. These parts-courts, regulatory agencies, executives, and even legislatures - are networking with their counterparts abroad, creating a dense web of relations that constitutes a new, transgovernmental order."). 
shape the constitution of the firm and those that form the body of labor law for the worldwide activity of business corporations and their employees are transnational in nature. Although numerous accounts of the scope and content of transnational law (TL) exist, the following sketch shall carve out the essential ideas as they apply to our theme of the separate worlds of corporate governance and labor law.

The first usage of the term TL continues to be disputed. While scholarship focused on the origins of the term for a long time, it has since become apparent that the real challenge of TL lies in its scope and conceptual aspiration. ${ }^{162}$ Within an interdisciplinary research agenda concerning the transformation of globalized law, TL offers itself as a supplementing and challenging category. Famously conceptualized in a series of lectures by Philip Jessup at Yale Law School in 1956, ${ }^{163}$ TL "breaks the frames" (Teubner) of traditional thinking about interstate relationships by pointing to the myriad forms of border-crossing relations among state and non-state actors.

Jessup writes that he "shall use ... the term 'transnational law' to include all law which regulates actions or events that transcend national frontiers. Both public and private international law are included, as are other rules which do not wholly fit into such standard categories." ${ }^{164}$ When examining the inescapable "problem" of people world wide whose lives are "affected by rules," Jessup points to the striking contingency by "which we attribute the label of 'law' to rules, norms or customs that govern various situations." It is the hallmark of TL to identify the hidden agendas and the blind spots of traditional regulatory law understandings. These are marked by clear assignments of law-making authority to certain institutions and a clear view of which norms of societal guidance are to be recognized as legal rules. In contrast, TL suggests a widening of the law-making agenda and of our understanding of law as such. TL emerges from the increasingly interlocking spheres of societal norm production by public, official and private, unofficial norm-setting agencies and actors.

Based on such an expanded understanding of law, TL has begun to reach deep into the heart of contemporary struggles over the role of law within dispersed and fragmented spaces and places of norm production. ${ }^{165} \mathrm{TL}$ reminds us

162. Jessup, supra note 115; Harold Hongju Koh, Transnational Legal Process, 75 NEB. L. Rev. 181 (1996).

163. Jessup, supra note 115.

164. Id. at 2.

165. For background on the distinction between spaces and places, see SASSEN, supra note 16. 
of the very fragility and unattainedness of law. At the beginning of the twentyfirst century, we are still at a loss to identify a theory of law that would be subtle enough not to stifle emerging identities in a post-colonial era, ${ }^{166}$ while providing "forms, fora, and processes" 167 for the collision of discourses that mark postmetaphysical legal thinking. ${ }^{168}$ It is against this background that our search continues for a legal theory that could adequately describe the complex regulatory environment identified earlier.

The transnational perspective on law allows us to identify the dehierarchized law-making processes across national borders. ${ }^{169}$ Building on Saskia Sassen's and Sousa Santos's work on the importance of the study of places and spaces of regulation, ${ }^{170}$ we can begin to discern the regulatory groundwork of globally integrated markets. Seen through a governance lens that parallels both the emerging governance structures and discourses on the national, transnational, and global level, the "domestic face of globalization" "171 becomes apparent, and "globalization" loses much of its supposedly foreign, "outside" character. And it is through the realization of similarities of legal and political struggles in other places that the shared place between those and our struggles becomes visible. It is against this background that the study of corporate codes of conduct may alert us to the challenges of empowering workers in fragmented work place realities that have been moved out of the reach of national regimes of labor law protection.

The task, therefore, is to create a transnational regulatory framework which encourages and develops the potential of TNCs to raise the labour standards of economically and socially disadvan-

166. See, e.g., Beth Lyon, Discourse in Development: A Post-Colonial Theory "Agenda" for the United Nations Committee on Economic, Social and Cultural Rights Through the Post-Colonial Lens, 10 A m. U. J. Gender Soc. Pol'y \& L. 535 (2003).

167. Wiethölter, supra note 40.

168. Jürgen Habermas, Paradigms of Law, 17 Cardozo L. Rev. 771 (1996); Jürgen Habermas, Between Facts and Norms: Contributions to a Discourse Theory of Law and Democracy (William Rehg trans., 1996).

169. See Jessup, supra note 115; Berthold Goldman, Frontières du droit et lex mercatoria, 9 ARChives de Philosophie de Droit 177 (1964); Clive M. Schmitthoff, Nature and Evolution of the Transnational Law of Commercial Transactions, in The Transnational LaW of International Commercial Transactions 19 (Norbert Horn \& Clive M. Schmitthoff eds., 1982); Koh, supra note 162; Teubner, supra note 47; Zumbansen, supra note 47.

170. SASSEN, supra note 16 ; SANTOS, supra note 48.

171. Aman, supra note 153. 
taged groups of workers and producers, particularly in the informal sector. At national level, the application and elaboration of this framework has to take account of the specific local cultural, social and economic features. We must, therefore, evaluate the emerging methods of transnational labour regulation according to their potential for the dissemination of "best practices" and for developing solidarity between workers employed by TNCs in different countries. ${ }^{172}$

TL thus illuminates the parallels between fragmented regulatory developments that no longer follow only the rules of state-based, statutory law making and enforcement through courts. At the same time, the transnational law of codes of conduct recalls the regulatory experiences within a specific, national regulatory environment, which regularly consists of contested strands of law, culture, and socioeconomic struggles. ${ }^{173}$ In this vein, TL contains the narratives of law's past as it is embedded in national histories of law as an instrument of social change. ${ }^{174} \mathrm{TL}$, then, can be seen as always aspiring to form a stable body of law, while it constantly unfolds as a regulatory experiment in a multipolar and multilevel socioeconomic environment. In that respect, the study of TL can sharpen our perception against the creation of allegedly "new rights," values, and principles that are being presented as something different from the regulatory rules and statutes that legal theory has been concerned with all along.

TL offers itself as a critique of the promises of private ordering increasingly detached from processes of legitimation and political accountability. From this perspective, the transnational law of labor law rights is in its infancy. ${ }^{175}$ For the time being, corporate codes of conduct appear to move forward at best a reductionist and complementary concept of labor law, where workers' rights are subjected to a wider corporate agenda of social responsibility instead of being developed within an effective regulatory framework of labor law. Meanwhile, in avoiding effective political regulation through national governments or international bodies, corporate codes of conduct remain regulatory instruments not

172. HePple, supra note 13 , at 21.

173. See Peer Zumbansen, Ordnungsmuster im modernen Wohlfahrtsstaat. LernerfahrunGen zwischen Staat, Gesellschaft und Vertrag 299-327 (2000).

174. See Koh, supra note 162 , at 186-91.

175. Arthurs, supra note 67. 
in the hands of those they are purportedly meant to protect but in the hands of their corporate authors alone.

While the localized regulation of corporate activity echoes earlier hopes of the advantages of decentralized governance in a wider system of regulatory competition, ${ }^{176}$ corporate codes of conduct will not enable workers to develop a sustainable regime of protected rights if they are not embedded in a sensitive and adequately responsive system of monitoring and revision. It is here where the spatial concept of public fora, organized in the vicinity of localized corporate activity, allows us to see the connections between different awareness initiatives by consumer groups, political activists, lobbying groups, and non-governmental organizations. ${ }^{177}$ From a methodological point of view, an effective supervision and control of code production and of the rights they endorse will require continuous monitoring efforts. Proposals such as a "rolling rule regulation," by Sabel, O'Rourke, and Fung, address the regulatory challenge that follows from a highly dynamic and asymmetrically structured law-making process. ${ }^{178}$ At the same time, we need to assess the regulatory potential of such proposals in light of the aforementioned importance of integrating prior regulatory experiences and struggles over democratic governance into our contemporary design of a regulatory framework for labor law.

In light of these challenges of decentralized and fragmented public fora, the political imagination undergoes dramatic adaptations. Consequently, the form and substance of the political process need to be reconsidered in light of dramatically increased problems of representation and identity issues. ${ }^{179}$ These must be seen as both the burden and the heritage of the "global bukowina." ${ }^{80}$ No "law without the state" ought to be developed in a state of amnesia as regards the

176. See generally Charles M. Tiebout, A Pure Theory of Local Expenditures, 64 J. Pol. Econ. 416 (1956) (showing that spending at a local level meets the public need more effectively than spending at a national level).

177. HePPle, supra note 13, at 84,273 ; Blackett, supra note 16 , at $436-39$ (discussing the differences among NGOs and the resulting difficulties for concerted action and effective workers' representation).

178. SABEL ET AL., supra note 136. This approach has been working effectively in the transnational law of consumer protection. Gralf-Peter Calliess, Grenzüberschreitende Verbraucherverträge [Transnational Consumer Contracts] ch. 5 (forthcoming 2006).

179. Upendra Baxi, Voices of Suffering, Fragmented Universality, and the Future of Human Rights, in The Future of International Human Rights (Burns H. Weston \& Stephen P. Marks eds., 1999).

180. Teubner, supra note 47. 
underlying and continuing distributive issues with which labor law has always been concerned. ${ }^{181}$ Accordingly, TL can help us recognize and assess pervasive discourses of legitimacy of the new world order in different fields of law. For example, in the law of corporate governance, we see that the current assertion of a globalized convergence to shareholder-value thinking tends to overlook many existing differences, even within different trajectories of capitalism. ${ }^{182}$

The differentiated picture that has been sketched in this paper owes much to the "Varieties of Capitalism" school, which has been casting a wider perspective on legal and socioeconomic institutions in order to better understand the trajectories of institutional change in the political economy of states. ${ }^{183}$ With regard to labor laws, this perspective allows us a richer understanding of the regulatory environment: "[labor] laws are but one element of a wider political economy that includes industrial relations, corporate governance, vocational education and training, and inter-firm relations." ${ }^{8+}$ And yet corporate governance, as it permeates the contemporary world of corporate self-regulation, is entirely informed by a global focus on investor protection: the definition of the business corporation, as much as the applicable laws, remains confined to a very narrow concept and understanding of corporate governance without accounting for the larger political economy in which both are embedded. It is here where new comparative research has taken its cue from the "Varieties of Capitalism" school while taking into account the "degree of recent political economic change that has occurred in recent years and the intensely political processes that construct corporate governance regimes." 185

The decoupling of corporate self-regulation and the ensuing privatization of labor law norm-setting standards seems to seriously frustrate any hopes of im-

181. Hepple, supra note 13 , at 256.

182. See generally AlBert, supra note 94 (comparing different approaches to corporate governance and enforcement); Peter A. Hall \& David Soskice, Introduction to Varieties of Capitalism, supra note 17, at 1; Cioffi, supra note 34; Mary O'Sullivan, The Political Economy of Comparative Corporate Governance, 10 Rev. INT'L Pol. Econ. 23 (2003).

183. Hall \& Soskice, supra note 182. See also David Soskice, Divergent Production Regimes: Coordinated and Uncoordinated Market Economies in the 1980s and 1990s, in Continutur and Change in Contemporary Capitalism 101 (Herbert Kitschelt et al. eds., 1999).

184. Hepple, supra note 13, at 253; accord Thelen, supra note 17.

185. Cioffi, supra note 57. 
proving the ailing situation of labor law regulation. ${ }^{186}$ In light of the larger trend toward deformalization in public international law, a (admittedly very) pessimistic reading would qualify any strengthening of labor rights and of workers' participation in corporate governance as an exception to the norm, as something to be ethically considered, if at all. Workers' rights would increasingly be seen as excluded from the "normal" realm of labor law on the one side and from the reach of corporate law on the other. Finally, as workers' rights become part of the voluntary ethics codes of a corporation, there is the risk they fall outside the reach of a more effectively enforceable regulation. In contrast, a more optimistic reading that would focus on the potential of a continuing supervision by transnational civil society actors faces the above-described challenges of providing for effectively linked, transnational monitoring and supervising instruments.

\section{B. Transnational Law and Constitutionalization}

"Law is important-but cannot be all there is, and it does not operate only in one way." 187

Some distance from the crystal palaces of transnational legal theory, survival battles over the resistance of labor laws to neoliberal agendas of economic globalization are being waged, and these battles serve as a constant reminder of how much depends on their outcome. In an angry article add ressing the World Commission Report of February 2004 on the "Social Dimensions of Globalization," Philip Alston and James Heenan discerned an emerging trend in constitutional thinking, which denies regulatory intervention. ${ }^{188}$ It comes as no surprise that the U.S. Supreme Court's decision in Lochner v. New York ${ }^{189}$ in 1905 serves as the case in point here, although notably and regrettably not Holmes's dissent. While American politics and jurisprudence did in many ways take a critical stance to-

186. Harry W. Arthurs \& Claire Mummé, From Governance to Political Economy: Workers as Citizens, Stakeholders and Productive Social Actors (2005) (paper for the First International CLPE Conference: The Corporate Governance Matrix: Unfolding the New Agenda, Osgoode Hall Law School, Toronto, Ontario, Candada, October 20-21 2005. See Comp. Res. in Law \& Pol. Econ. Website, http $/ /$ www.comparativeresearch.net).

187. Langille, supra note 19 , at 417.

188. Alston \& Heenan, supra note 146, at 228.

189. 198 U.S. 45 (1905). 
ward Lochner in subsequent years, ${ }^{190}$ this reversal seems to be forthcoming. Alston and Heenan fear that, in the wave of antiregulatory politics and nurtured by an ideologically self-righteous neoliberal agenda, the Lochner Court might now be seen to have promoted better "economic theory" when it interpreted the due process clause as endorsing the principle of freedom of contract, something that Holmes so powerfully deconstructed in his dissent. All is in the present, and the past is forgotten. With it, all the lessons of the past seem to be forgotten as well; the lessons from Holmes's dissent have powerfully and rightly been drawn, for example, by the American realists, ${ }^{191}$ but also by current work in law and development. ${ }^{192}$

In recalling the way in which Holmes deciphered the Court's embrace of abstract principles and its deduced legal rules from abstract principles, we can return to the wonderful story told by Felix Cohen about Rudolf von Jhering's dream of being in a heaven of abstract notions. ${ }^{193}$ In his dissent, Justice Holmes convincingly pointed out that nothing can be seen as either being entailed or excluded by way of concrete outcomes from the recognition of rights in the abstract form. Rights, as such, are not a guarantee of either legal or social transformation: it is only at the level of practice, typically in the context of a specific dispute, that their uses are determined. ${ }^{194}$

The core of the debate over corporate codes of conduct must be discovered in the underlying understanding of the law. This core is explosive, as it can again be split. On the one hand, we find formalism, a discourse on "rights" and on law as assigned power. On the other hand, we find the embeddedness of law. Here, we find law as embedded in the greater political economy of its last battle against a globalized corporate Moloch. But these distinctions betray their own impossibil-

190. See West Coast Hotel Co. v. Parrish, 300 U.S. 379 (1937); Morton J. Horwitz, The Transformation of American Law: 1870-1960, at 33-63 (1992); Hepple, supra note 13, at 260-61.

191. See, e.g., Robert L. Hale, Bargaining, Duress, and Economic Liberty, 43 Colum. L. Rev. 603 (1943); Robert L. Hale, Coercion and Distribution in a Supposedly Non-Coercive State, 38 PoL. Scr. Q. 470 (1923).

192. David Trubek \& Marc Galanter, Scholars in Self-Estrangement: Some Reflections on the Crisis in Law and Development Studies in the United States, 1974 WIs. L. Rev. 1062; Jeswald W. Salacuse, From Developing Countries to Emerging Markets: A New Era for Law and Development, in Festschrift für Bernhard Grossfeld zum 65 Geburtstag 959 (Ulrich Hübner and Werner F. Ebke eds., 1999).

193. Felix S. Cohen, Transcendental Nonsense and the Functional Approach, 35 Colum. L. Rev. 809 (1935).

194. See Kerry Rittich, Enchantments of Reason/Coercions in Law, 57 U. Miami L. Rev. 727 (2003). 
ity as well as their ideological motivation. Certainly, then, we find excitement and unrest on both sides: Brian Langille, himself a long-standing expert on international labor law and the ILO, rejects Alston's lament that core labor rights undermine the formerly endeared promise of global labor rights ${ }^{195}$ as promoted by the ILO as "romanticism" and "hallucination." 196 Laws exist, Langille posits, "not as ends in themselves but for the welfare of society." 197 True, but what does that mean? Langille's argument, while being presented as forcefully as the one he opposes, proceeds indirectly, making passes through neighboring territory to show that one needs to take a wider view on things. The procession of the argument is simple, straightforward, and, at the same time, very sophisticated. It is, indeed, both authors'-Alston's and Langille's-approach to the issue that will likely make this dispute one that will retain currency in the discussion over the ILO and the nature of the international labor law regime in the years to come-not to mention its value for a legal theory seminar on legal argumentation.

Countering Alston's concern about the ILO losing its influential position in the shaping of an international labor law regime, Langille smartly responds, "I have never heard anyone, inside the ILO or out, claim that the ILO was at centre stage in any meaningful sense. ${ }^{198}$ In this part of the argument we can recognize the operation of elements of space. ${ }^{199}$ For Alston, the ILO's loss of its important position in the space of labor law regulation is ascribed to its embrace of neo-liberally induced core labor rights that will, according to Alston, replace an allegedly more effective system of rights protection under the auspices of the ILO in Geneva. ${ }^{200}$ Langille continues to operate in spatial imagery in order to identify Alston's very premise as false. Rejecting the ILO's occupation of a central regulatory place and, instead, situating the ILO at the margins of global market regulation, Langille prepares the ground for his substantively more positive assessment of the ILO's core labor rights program. Langille situates the ILO at some hard spot in the complex regulatory, multilevel environment of international labor law in order to further illuminate the regulatory challenge that the ILO faces.

195. See Alston, Core Labour Standards, supra note 19.

196. Langille, supra note 19 , at 417.

197. Id.

198. Id. at 418.

199. SASSEN, supra note 16, at 97 ; S ANTOS, supra note 48 . For an application in the area of corporate codes of conduct, see Blackett, supra note 16. For a parallel perspective on the de-centralized, spatial development of transnational corporate governance, see Zumbansen, supra note 16.

200. Alston, Core Labour Standards, supra note 19, at 458; Alston, Facing up, supra note 19, at 470. 
The idea that there is a centre stage and that it is located in Geneva is probably a bad idea to start with. The international labor law regime is probably, and probably always was, much better regarded as a very complex motley of actors, sites of contest, modes of action, at different levels, etc., probably without a single centre and shifting overtime. ${ }^{201}$

In his reply, Alston sticks to the space and centrality perspective to reflect on the importance of the ILO in shaping the international labor law regime-from Geneva into the world through its manifold communications to national labor law regulators. ${ }^{202}$

From within the critique of the space imagery employed by Alston, Langille moves to the legal core of the dispute over core labor rights. Where Alston suspects that the ILO-through its 1998 Declaration-conducted a shift from rights to principles, Langille interprets the ILO's embrace of principles ("freedoms") in its Declaration as a clear sign for just the opposite movement, reading this as "a shift from international labor standards to international labour/human rights." ${ }^{203} \mathrm{Al}-$ ston replies that the ILO and existing labor law retain enough rights and that "a wide range of corporate and other actors need to be mobilized in that endeavor."204 To this, Langille responds that, in fact, the ILO's embrace of standards and core labor rights is not only in line with the ILO's traditional mode of norm setting, but that the 1998 Declaration can also be seen as faring more successfully in the overall implementation programs through Member States. ${ }^{205}$ "The fact is that the techniques at the ILO were and are soft." 206 With conventions now encompassing standards over long and detailed lists of rights to be ratified, the result is that the newer conventions get overwhelmingly ratified. ${ }^{207}$

201. Langille, supra note 19, at 419.

202. Alston, Facing up, supra note 19, at 469-70.

203. Langille, supra note 19 , at 422.

204. Alston, Facing up, supra note 19, at 470.

205. "For labour lawyers this distinction between labour standards and labour rights is fundamental and sounds in the basic conceptual map that labour lawyers use to frame and justify their field. This map is the basic story, narrative, framework of thought, call it what you will, which labour lawyers tell themselves, and it them, about what makes labour law labour law, and why it is worth worrying about." Langille, supra note 19 , at 428.

206. Id. at 423 .

207. Id. at 425 . 
In order to identify the problem posed by those suspicious that the introduction of human rights standards in the international labor law regime represents merely an inside attack on the labor law regime, Langille builds on ${ }^{208}$ the "capability' theory" that Amartya Sen had developed in his book, Development as Freedom. ${ }^{209}$ Applying Sen's approaches, Langille contemplates shifting the perspective in legal regulation: "Promotion is not a bad substitute for "enforcement'."'10 The intriguing thrust of Langille's argument of promoting human freedom is that the introduction of labor standards might help countries to reflect on what their real interest is in protecting and promoting human freedom. And it is this task that others will hold them accountable for. ${ }^{211}$ When confronted, it turns out that both sides share more than was visible at first. Alston points out that the core of the international human rights regime is not, and has never been, about "enforcement." 12 Instead, the main thrust of international human rights is about "empowerment and mobilization." 213 With regard to the ILO, this points in the direction of further institutional and procedural reform, allowing the Organization to become more responsive and susceptible to "new actors including corporations and those promulgating codes of conduct."214

This multilevel and multipolar regulatory environment forms the framework in which we can observe the emergence of overlapping legal discourses such as labor law and human rights, hard and soft law, or labor law and corporate governance. Shining through these discourses we may hope to find traces of constitutional law with regard to determination of a new legitimacy basis for the dramatic developments in regulatory governance. Constitutions easily become fetishes, concepts of silencing, or overwhelming authority, as they embody values and principles in a highly abstract manner. It is this tension, which

208. Id. at 432 .

209. Amartya Sen, Development as Freedom (1999). In his groundbreaking work, Amartya Sen famously argued for an approach in development policy that emphasizes the growth and development of human capabilities to lead their lives according to their own disposition. While public policy would have to target such development, it should at the same time be influenced and shaped by participatory input from those engaged in the developmental process. Id. at 18-20.

210. Langille, supra note 19 , at 434 .

211. Id. at 436.

212. Alston, Facing up, supra note 19, at 479.

213. Id. at 473 .

214. Id. at 479 . 
informs the contemporary assessments of constitutionalization of TL. ${ }^{215}$ But, can we dismiss any thought of constitutional thinking when we are asked to reevaluate the boundaries of private laws with a public function? ? $^{216}$

It is one of the great legacies of the early beginnings of American legal realism to have argued that the dissociation of abstract principles from their real-life application reifies the former, while providing no satisfactory explanation for the latter. The isolation of constitutional values from their practice (Holmes) leads us to forget (1) the institutional framework in which the constitution has been interpreted and functioning all along, and (2) the distributive effects of the legal and socioeconomic environment in which the constitution, or, for that matter, any other statute or norm has been interpreted. This means for core labor standards that they too are not different from regulation; they are just another form of regulation, and they have to be analyzed with the same analytical framework that we hold as adequate elsewhere.

Where self-regulation has the effect of placing workers at the mercy of management without the availability of institutional safeguards, this form of private ordering remains deficient. It is then not through the revival of traditional forms of collective bargaining, as were available in the post-war labor law regimes, but through new modes of interest representation, monitoring, and the securing of transparency that first steps toward the reestablishment of workers' voice and participation may be taken. But, even while much seems to suggest that we must turn our attention to the viable role that can be played by a wider circle of interest groups, the break with prior existing forms of collective bargaining again becomes painfully evident. Indeed, where self-regulating multinational corporations and their codes of conduct can be seen to render the loss of entitlement and participation rights invisible, corporate codes of conduct will remain unsatisfactory instruments of workers' empowerment.

Placing an abstract idea of market self-regulation in opposition to the idea of state intervention makes either of these nonsensical. Furthermore, it assumes they are something different. Yet, the market itself is not unregulated. ${ }^{217}$ Instead, the market produces distributions of outcomes and power through the actors and norms operating in it. The appeal of corporate social responsibility and of

215. See Teubner, supra note 47. For a critique, see David Schneiderman, Investment Rules and the New Constitutionalism, 25 L. \& Soc. Ineviry 757 (2000).

216. See Karl N. Llewellyn, What Price Contract?-An Essay in Perspective, 40 Yale L.J. 704 (1931).

217. See id.; Polany 1 supra note 11 , at 71-80. 
labor norms incorporated in corporate codes of conduct can be seen in the fact that they are commonly assumed to be neutral and "nonregulatory." By allegedly being mere principles instead of conflictual rights, they are not seen as impeding on the otherwise performed discretion of a market regulator.

Against this background, how can we describe an alternative vision of constitutionalizing the TL of corporate governance and of labor laws? Attaining a more effective protection of workers' rights would take a courageous and yet careful approach to multilevel, decentralized, and mixed public and private governance. Its approach would have to be courageous in its embrace of the exhaustion of traditional nation-state based or-on the international level-statebased regulatory institutional approaches in favor of context-sensitive models of reflexive law and responsive regulation. At the same time, it would need to be careful in remaining aware of the preceding and continuing political and social struggles over participation, representation, entitlement, voice and exit, and, eventually, loyalty. ${ }^{218}$ It would, furthermore, have to be careful and sensitive of the continuing challenge in translating constitutional visions developed in a different regulatory and socioeconomic environment onto the transnational level. ${ }^{19}$ This sensitivity would have to allow for awareness of the continuing tension between the daily, awfully quiet and routine practice of law, and its increasing moments of crisis, emergency, and exception. The development of a constitutional dimension of TL would then perhaps allow us to remember that at the outset of a decision for or against a regulatory option, there is always a normative dilemma. ${ }^{220}$ That dilemma still exists regardless of which regulatory approach is resolved upon in the end. The undeniable dilemma-a dilemma that lies at the heart of the debate over core labor rights and corporate codes of conduct, the "Trade and ..." discussions, the struggle over the rule of law projects of the World Bank, the policy recommendations by the IMF, and also of the world wide discussion over the alleged convergence of corporate governance systems towards a shareholder-value-oriented model all involve many questions.

218. See generally Albert O. Hirschman, Exit, Voice, and Loyalty: Responses to Decline in Firms, Organizations, and States (1970). For an intriguing application with regard to shareholders, see David C. Donald, Shareholder Voice and Its Opponents (Inst. for Law \& Fin. (Frankfurt), Working Paper Series No. 40, 2005), available at http://publikationen.ub.uni-frankfurt.de/ volltexte/2005/1113/pdf/ILF_WP_040.pdf.

219. See Neil Walker, Postnational Constitutionalism and the Problem of Translation, in European Constitutionalism Beyond the State 27 (J.H.H. Weiler \& Marlene Wind eds., 2003).

220. See Lon L. Fuller, Positivism and Fidelity to Law-A Reply to Professor Hart, 71 Harv. L. Rev. 630,672 (1958). 
These questions include: whether and which role workers are to play in the constitution of the firm; whether workers' financial, safety and organizational rights must be seen in connection with the promotion of trade policy; whether financial stability as a policy requirement for international financial aid is meant to include respect for a country's political choices for or against a strong welfare system; or whether financial stability can only be achieved through politics of privatization and deregulation. 

